
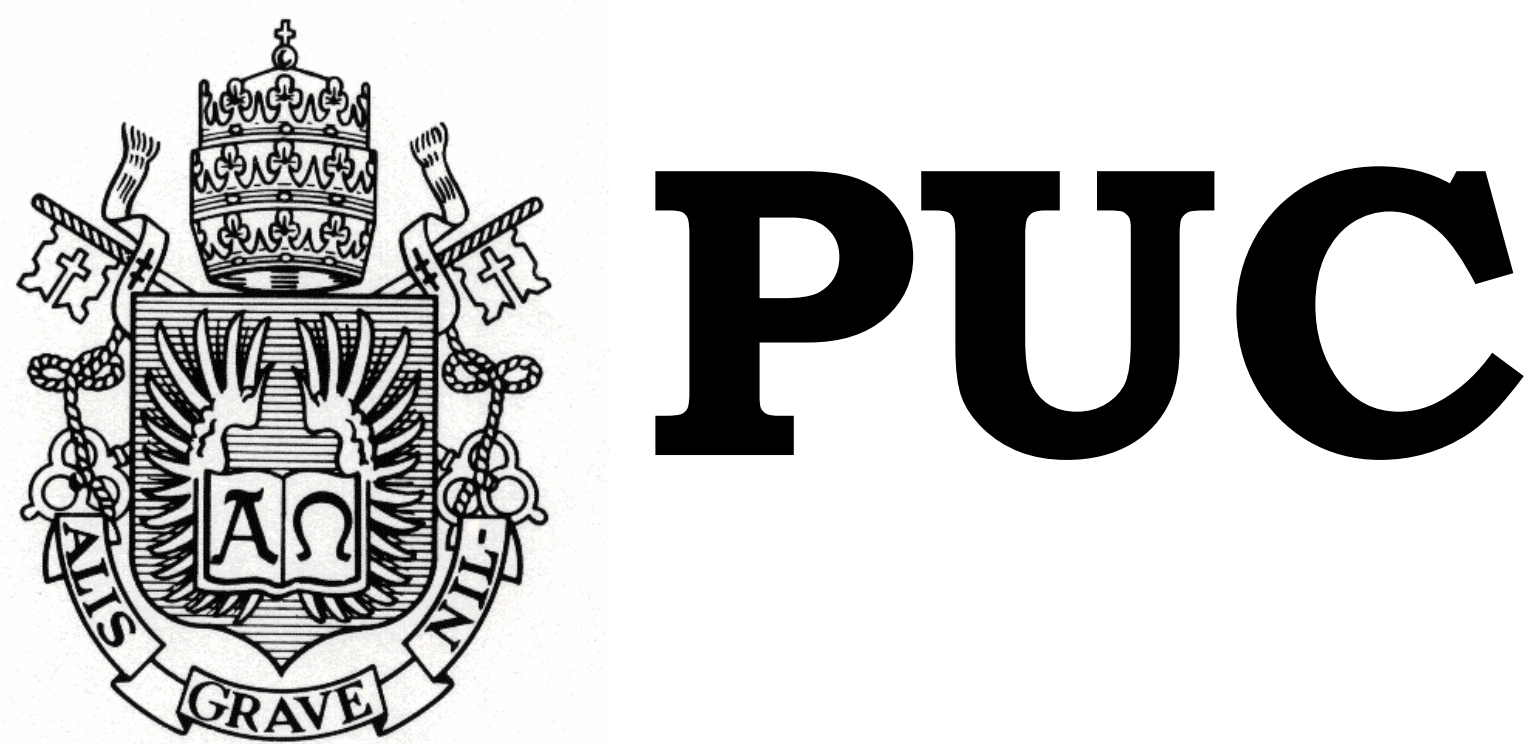

DEPARTAMENTO DE DIREITO

\title{
AS INTERCEPTAÇÕES TELEFÔNICAS E SUA APLICAÇÃO EM MATÉRIA PENAL
}

por

MARIA CLARA JORGE RIBEIRO SOARES

Orientadora: Victória-Amália de B.C.G. de Sulocki 2010.2

PONTIFÍCIA UNIVERSIDADE CATÓLICA DO RIO DE JANEIRO -

RUA MARQUÊS DE SÃO VICENTE, 225 - CEP 22453-900

RIO DE JANEIRO - BRASIL 


\title{
AS INTERCEPTAÇÕES TELEFÔNICAS E SUA APLICAÇÃO EM MATÉRIA PENAL
}

\author{
por \\ MARIA CLARA JORGE RIBEIRO SOARES
}

Monografia apresentada ao

Departamento de Direito da Pontifícia Universidade Católica do Rio de Janeiro (PUC-Rio) para a obtenção do Título de Bacharel em Direito.

Orientador: Victória-Amália de B.C.G. de Sulocki

2010.2 


\section{Resumo}

As Constituições brasileiras, salvo a outorgada em 1937, sempre preservaram, de forma absoluta, a garantia da privacidade do indivíduo, o que, de um modo geral, estava em consonância com a Constituição de outros países do mundo democrático.Entretanto, a Carta Republicana de 1988, em seu art. 5º inciso XII, inobstante continue, como regra, garantindo a inviolabilidade da privacidade, excepcionou tal regra, de modo a permitir a interceptação telefônica "por ordem judicial, nas hipóteses $\boldsymbol{e}$ na forma que a lei estabelecer para fins de investigação criminal ou instrução processual penal'. Diante de tal exceção, alguns autores e tribunais passaram a entender que a norma constitucional era autoaplicável, isto porque o Código Brasileiro de Telecomunicações - Lei ${ }^{0}$ 4.117/62 -, estabelecia que não constituía violação de telecomunicações “o conhecimento dado ao juiz competente, mediante requisição ou intimação deste”.O tema foi levado a julgamento pelo Plenário da Suprema Corte, que decidiu no sentido de que a exceção constante da norma constitucional somente poderia ser aplicada após a edição de lei ordinária que disciplinasse a matéria.Em face dessa decisão, o Poder Executivo encaminhou Projeto de Lei ao Congresso, daí surgindo a Lei nº 9.296/96, que passou a regular a quebra do sigilo e interceptação de comunicações telefônicas.Como toda a lei que estabelece exceções, vários dispositivos dessa Lei passaram a ser questionados pela doutrina e pela jurisprudência de nossos tribunais, sendo de se ressaltar que, ainda hoje, inexiste posicionamento manso e pacífico acerca de sua aplicação em determinados casos.No trabalho que ora apresentamos, procuramos tecer algumas considerações quanto às normas mais discutidas dessa Lei, valendo-nos, sobretudo, do entendimento jurisprudencial que nossos tribunais estão dando à matéria.Procuramos, outrossim, fazer uma abordagem quanto a algumas das questões mais controvertidas em termos doutrinários.Concluímos demonstrando que a lei tem sido utilizada de forma abusiva, o que ensejou, inclusive, a intervenção da Corte Interamericana de Direitos Humanos, que veio a condenar o Estado brasileiro pela inobservância das formalidades legais em determinado caso que foi levado à sua apreciação. 
Dedicatória

Dedico este trabalho a minha família, pelo apoio dado durante todo o curso e ao meu namorado. 


\section{Agradecimentos}

Agradeço a minha orientadora, aos meus amigos pelo apoio, e a minha família, principalmente meu pai, pela compreensão e elaboração do trabalho realizado. 


\section{Sumário}

Capítulo I - INTRODUÇÃO …………………………………………………..

Capítulo II - DIREITO À PRIVACIDADE VISTO POR OUTRAS

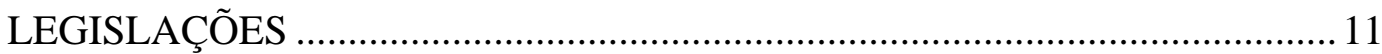

Capítulo III - DISCUSSÃO QUE ANTECEDEU À EDIÇÃO DA LEI No

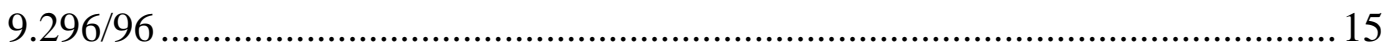

Capítulo IV - DA APLICAÇÃO DA LEI N 9 9.296/96 ............................................24

Capítulo V - CONSIDERAÇÕES SOBRE ALGUMAS DAS NORMAS DA LEI

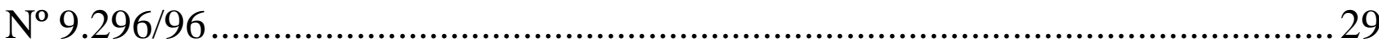

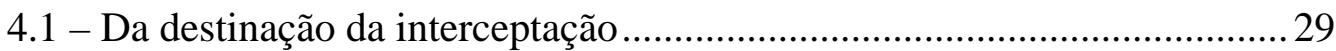

4.2 - Do juiz competente para decretar a interceptação ……………………….... 30

4.3 - Da preservação do segredo de justiça .......................................................... 31

4.4 - Sem indícios razoáveis de autoria ou participação em delito não se admite interceptação das comunicações telefônicas ............................................ 34 4.5 - Só a impossibilidade da prova ser feita por outros meios permite a

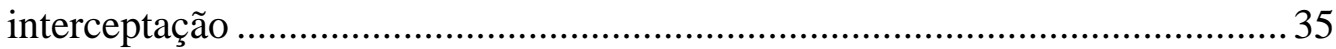

4.6 - Infração penal punida com detenção não autoriza a interceptação............ 38

4.7 - A decisão que decreta a interceptação terá que ser devidamente

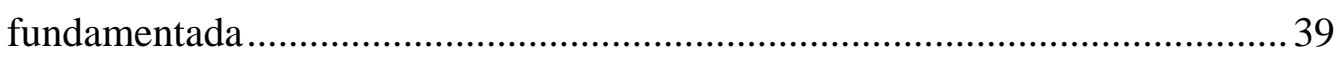

4.8 - Do prazo de duração das interceptações ..................................................... 41

4.9 - Do delito cometido em razão de interceptações ilegais .............................. 47

4.10 - Pode o Juiz, “de ofício” não pode determinar interceptação .................... 50 
Capítulo V - QUESTÕES CONTROVERTIDAS

55

5.1 - Comissão Parlamentar de Inquérito pode decretar Interceptação telefônica ? 55

5.2 - As conversações dos advogados com os seus clientes não podem ser

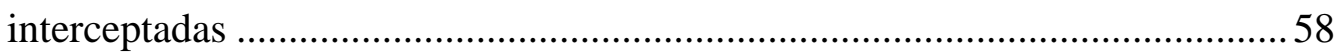

5.3 - Denúncia anônima não autoriza o deferimento de interceptações

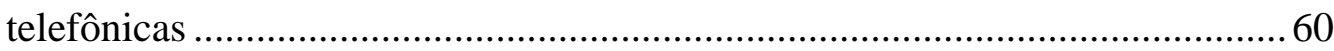

5.4 - Podem as interceptações serem utilizadas - Para outros fins probatórios 65

Capítulo VI - A INTERVENÇÃO DE CORTES INTERNACIONAIS QUANTO AOS EXCESSOS PRATICADOS .69

VII - CONCLUSÃO 73

REFERÊNCIAS BIBLIOGRÁFICAS 79 


\title{
Capítulo I - INTRODUÇÃO
}

A interceptação das comunicações telefônicas é medida que, inegavelmente, atinge a privacidade e intimidade do cidadão, afastando o seu direito de ser deixado em paz, sem que sofra qualquer ataque, público ou privado, quanto às condutas que deseja individuais ou, quanto muito, limitadas a um certo número de pessoas.

Na antiguidade entendia-se que com a proteção à propriedade estarse-ia defendendo a privacidade, mas, com o passar do tempo, os juristas passaram a definir a privacidade como sendo o direito de uma pessoa ser deixada em paz para levar sua própria vida com o mínimo de ingerências exteriores.

JOSÉ AFONSO DA SILVA, ao equiparar o direito à intimidade com a privacidade, destaca :

\begin{abstract}
“A expressão direito à privacidade, num sentido genérico e amplo, abarcaria todas as manifestações da esfera intima, privada e da personalidade, que o texto constitucional em exame consagra. Seria o conjunto de informações acerca do indivíduo que ele pode decidir manter sob seu exclusivo controle, ou comunicar, decidindo a quem, quando, onde e em que condições, sem a isso ser legalmente sujeito. A esfera de inviolabilidade, assim, é ampla, abrangendo o modo de vida doméstico, nas relações familiares e afetivas em geral, fatos, hábitos, local, nome, imagem, pensamento, segredos, e, bem assim, as origens e planos futuros dos indivíduos" 1
\end{abstract}

As grandes concentrações humanas nas cidades, seja nos locais de trabalho e nas moradias, o progressivo aumento da população, a crescente necessidade de informação e muitos outros fatores que caracterizam o mundo moderno, notadamente, o avanço tecnológico, induziu os sistemas

\footnotetext{
${ }^{1}$ SILVA, José Afonso da. Curso de Direito Constitucional, 11ª ed., São Paulo, Malheiros, 1996, pág. 202
} 
jurídicos à tomada de posição definitiva na defesa dos indivíduos contra as ameaças de violação de sua vida privada.

Assim, a vida privada passou a constituir-se no direito de excluir-se da informação alheia idéias, fatos e dados pertinentes ao cidadão.

Entretanto, o surgimento de novas técnicas possibilitaram que mais e maiores atentados à privacidade fossem praticados, por meio de processos acústicos, óticos e, sobretudo, por meio de computadores e outros aparelhos que permitem a escuta de conversações telefônicas e normais.

Diante de tal realidade, o direito não poderia deixar de intervir e, por isso, vários foram os países que incluíram em suas legislações normas protetoras da privacidade.

No caso brasileiro, a hoje considerada inconstitucional Lei de Imprensa (Lei $n^{\circ}$ 5.250/67), introduziu a primeira referência legislativa expressa à vida privada, tornando-a objeto de proteção mediante reparação de danos, mesmo que verdadeira a divulgação, desde que ofensiva e não fosse motivada por interesse público.

As Constituições brasileiras, sem qualquer ressalva, sempre preservaram a privacidade, sendo que a do Império, em seu art. 179, 27, estabelecia que “o segredo das cartas é inviolável”, enquanto que as que a seguiram passaram a dispor que “é inviolável o sigilo da correspondência”.

A Constituição de 1937, como se sabe, foi inspirada na Constituição de Vaimar, sendo que esta em seu art. $117,1^{\mathrm{a}}$. parte, preceituava : “ $\boldsymbol{O}$ segredo das cartas, assim como o postal, telegráfico e o telefônico, são invioláveis", mas, em sua $2^{\mathrm{a}}$. parte dizia, expressamente, que as leis do Reich poderiam admitir exceções. 
Por essa razão, a Constituição brasileira, em seu art. 122, 6, embora continuasse preservando a privacidade, também fez ressalva, tanto que estabelecia : “a inviolabilidade do domicílio e de correspondência, salvas as exceções expressas em lei”, mas, tal exceção deixou de ser prevista na Constituição de 1946, que voltou à tradicional garantia : “é inviolável o sigilo da correspondência”.

Inobstante os textos constitucionais apenas se referissem à “correspondência”, nunca pairaram dúvidas de que os mesmos protegiam não só a postal, mas, também, a telegráfica e qualquer outra, como sempre foi sustentado pelo saudoso mestre PONTES DE MIRANDA.

Em 1962, a Lei nº 4.117 - Código Brasileiro de Telecomunicações em seu artigo 57, inciso II, alínea “e”, tratou do tema da violação de telecomunicações, prevendo não constituir violação de telecomunicações, “o conhecimento dado ao juiz competente, mediante requisição ou intimação deste”.

Como ressaltado em voto proferido na Excelsa Corte, pelo Ministro SEPÚLVEDA PERTENCE, “ $a$ escuta telefônica foi amplamente utilizada sob o regime autoritário, pelos organismos de informação e de repressão política : a questão de sua ilicitude não se constituiu, porém, senão raríssimamente, em tema de discussão judicial, fosse pela vigência exclusivamente nominal das garantias constitucionais, fosse porque, de regra, efetivada clandestinamente, poucas vezes a “degravação” das conversas telefônicas interceptadas tenha sido levada aos autos dos processos".

De fato, embora não apresentadas de forma ostensiva, tem-se notícia de que nesse período a escuta telefônica foi a determinante da efetivação de inúmeras prisões e serviu de meio para a obtenção de confissões perante os órgãos repressivos, notadamente, aqueles vinculados às Forças Armadas. 
Mas, diante da previsão contida na Lei $n^{\circ}$ 4.117/62, a interceptação telefônica passou a ser objeto de questionamentos perante os Tribunais, como, também, de pronunciamentos doutrinários, isto porque a Constituição de 1967 veio a fazer expressa menção às comunicações telefônicas, preservando, todavia, a sua inviolabilidade, face ao preceito contido no artigo 153, § $9^{\circ}$ : "É inviolável o sigilo da correspondência e das comunicações telegráficas e telefônicas".

Surge, então, a Constituição Federal de 1988 que, em seu inciso XII, do artigo $5^{\circ}$, garantiu, em princípio, a inviolabilidade das comunicações privadas em geral, mas, quanto às comunicações telefônicas, apresentou exceção, desde que a interceptação se efetivasse "por ordem judicial, nas hipóteses e na forma que a lei estabelecer para fins de investigação criminal ou instrução processual penal”. 


\section{Capítulo II - DIREITO À PRIVACIDADE VISTO POR OUTRAS LEGISLAÇÕES}

Atualmente, as regras constitucionais de outros países quanto à preservação da privacidade pouco diferem das existentes no direito pátrio. Os países democráticos, como regra, procuram inviabilizar a quebra do sigilo das comunicações telefônicas, de modo a que seja mantido o direito à intimidade do cidadão. Entretanto, na mesma linha do que dispõe a Carta Magna de 1988, excepcionam essa garantia para permitir que lei infraconstitucional discipline os casos permitidores de tal violação.

Assim é que a Constituição portuguesa, em seu art. 26, nº 1, consagra o direito à palavra, à reserva da intimidade da vida privada e familiar, enquanto que no art. $34, \mathrm{n}^{\circ} 4$, prevê a inviolabilidade do domicílio, da correspondência e das telecomunicações. Contudo, no art. $18, \mathrm{n}^{0} 2$, admite a restrição a esses direitos, o que, no caso das escutas telefônicas, está prevista no art. 187, do Código de Processo Penal, que, além de elencar os crimes que autorizam a interceptação, só a admite para aqueles puníveis com pena de prisão superior, no seu máximo, a três anos.

A Constituição espanhola, no art. 18, n ${ }^{0} 1$, também garante o direito à honra, à dignidade pessoal e familiar, sendo que no $\mathrm{n}^{0} 3$, assegura $\mathrm{o}$ segredo das comunicações, notadamente, das postais, telegráficas e telefônicas, salvo ordem judicial. Pela Lei Orgânica $n^{0}$ 04/88 foram estabelecidas as situações de suspensão desse direito fundamental, as quais, normalmente, são concedidas por decisão judicial, mas, em casos excepcionais e urgentes, podem ser autorizadas pelo Ministro do Interior ou Diretor de Segurança do Estado, sujeitas, todavia, a confirmação judicial posterior. 
Para o direito alemão a busca da verdade real não pode afrontar a preservação dos direitos fundamentais do cidadão, sob pena de ser considerada ilícita a prova obtida. Por isso, tanto a doutrina como a jurisprudência entendem ser inviolável e absoluto o sigilo da correspondência e das comunicações telefônicas, uma vez que as interceptações são tidas como violação à Constituição.

Entretanto, levando em consideração a teoria da proporcionalidade, também excepcionou a garantia, passando a admitir sua violação nos crimes contra a segurança nacional, a ordem pública, homicídio voluntário premeditado, falsificação de moeda, seqüestro, rapto, tráfico de mulheres, estelionato e os crimes de perigo social, previstos no art. 138, do Código Penal.

Como acontece com o direito espanhol, as interceptações, como regra, são decretadas pelo judiciário, mas, em casos de urgência, podem ser ordenadas pelo Ministério Público, sujeitas, contudo, à convalidação judicial.

Do mesmo modo posiciona-se o direito italiano, eis que sua constituição consagra a inviolabilidade do sigilo da correspondência e das comunicações, mas, abre algumas exceções, desde que a medida seja motivada da autoridade judiciária e esteja dentro dos limites estabelecidos pela lei.

Nesse contexto, após algumas revisões legislativas, a regulamentação das interceptações telefônicas passou a ser definida pelo art. 266, do Código de Processo Penal, que somente admite sua violação nos crimes dolosos, para os quais a pena cominada seja de reclusão superior a cinco anos, crimes contra a administração pública com pena de reclusão não inferior a cinco anos; crimes relacionados a substâncias entorpecentes ou 
psicotrópicos, a armas ou substâncias explosivas, contrabando e crimes referentes a injúria, ameaça, incômodo ou distúrbio às pessoas por meio do telefone.

Tal como algumas legislações já examinadas, o Código de Processo italiano admite que, em casos de urgência e para evitar demora que possa ser prejudicial às investigações, o Ministério Público pode proceder à interceptação por meio de decisão motivada, a qual, de imediato, deve ser comunicada ao juiz competente que, de pronto, decidirá sobre a sua convalidação.

Vale destacar que o $\S 3^{\circ}$, do art. 267, do Código de Ritos, estabelece que a decisão do Ministério Público, além de determinar como a interceptação deve ser realizada, também tem que indicar o tempo de sua duração, o qual não pode ser superior a 15 dias, podendo, entretanto, ser prorrogado pelo juiz, mediante decisão motivada, por período sucessivo de 15 dias, desde que continuem presentes os pressupostos autorizadores da medida excepcional.

Nos Estados Unidos, a orientação jurisprudencial sobre a relação entre as interceptações e a IV Emenda Constitucional, tem se posicionado no sentido de que, como regra, é proibido interceptar as comunicações telefônicas. No entanto, várias exceções teem sido admitidas, as quais podem ser impostas pela autoridade judiciária com a finalidade de obter prova para certas infrações penais.

O que não se encontra na legislação de outros países é a previsão de que, em casos justificados pela urgência, possa a autoridade policial fazer a interceptação, ainda que sem prévia autorização judicial, o que é admissível nos Estados Unidos. 
Por evidente, a nossa proposta não poderia ser no sentido de examinar o tema frente à legislação de todos os países e, por isso, optamos em apenas focalizar aquelas que apresentam alguma similitude com a legislação brasileira, mas, realçando que os países que primam pelo regime democrático, mesmo com exceções, garantem a privacidade do indivíduo.

O que é certo é que a doutrina revela que as exceções somente devem ser utilizadas quando as interceptações forem imprescindíveis à investigação, forem objeto de decisões judiciais devidamente fundamentadas ou que passem pelo seu crivo e que tenham duração que não se eternize.

Um outro aspecto que vem sendo destacado pela doutrina é que não se deve atribuir o caráter de imputado a alguém para se pleitear a interceptação telefônica e através dela investigá-lo, mas, ao contrário, primeiro investigá-lo e, depois, caso impossível a obtenção da prova, utilizar-se a interceptação. 


\section{Capítulo III - DISCUSSÃO QUE ANTECEDEU À EDIÇÃO DA LEI No 9.296/96}

Pelo que se expôs verifica-se que o Código Brasileiro de Telecomunicações estabelecia que não constituía violação de telecomunicações, "o conhecimento dado ao juiz competente, mediante requisição ou intimação deste”, enquanto que a norma constitucional, apesar de manter, como regra, a inviolabilidade das comunicações telefônicas, apresentou exceção, desde que a interceptação se efetivasse "por ordem judicial, nas hipóteses e na forma que a lei estabelecer para fins de investigação criminal ou instrução processual penal”.

Daí surgiu o questionamento : para que fosse vulnerada a norma constitucional poderia ser utilizada a Lei $n^{0} 4.117 / 62$ ou a exceção estaria atendida por essa lei ?

Alguns julgados, principalmente do SUPERIOR TRIBUNAL DE JUSTIÇA, assim como alguns autores, passaram a entender como satisfeita a reserva de lei prevista no texto constitucional, sob o fundamento de que houve a recepção da norma da lei ordinária.

Entretanto, o entendimento majoritário direcionou-se no sentido de que tal recepção inocorreu e, para isso concluir, foi de fundamental importância a utilização do direito comparado predominante nos Estados Unidos e na Europa, onde as leis que regem a autorização judicial à escuta telefônica para fins de investigação criminal, fiéis à natureza de exceção à garantia constitucional que a permissão há de ter, são todas minuciosas, começando pela enumeração taxativa dos delitos cuja repressão possibilitará a interceptação, assim como determinam a disciplina 
procedimental do pedido, as razões para a autorização e a forma da execução da diligência, de modo a restringi-la ao estritamente necessário.

Dentre nós, o entendimento que maior ressonância teve foi o de ADA PELLEGRINI GRINOVER que repelia, de forma explícita, a pretendida recepção, para os fins do artigo $5^{\circ}$, inciso XII, do citado artigo 57, do Código Brasileiro de Telecomunicações, salientando :

"Evidente que enquanto não vier a lei a estabelecer as hipóteses e a forma em que as interceptações poderão ser permitidas, não haverá, por enquanto, como ordenálas, pois o Código de Telecomunicações nada especifica, não suprindo a ausência de lei específica”. ${ }^{2}$

De fato, a manifestação da ilustre jurista que, diga-se de passagem, teve a adesão de outros renomados processualistas, mostrava-se irrespondível, na medida em que o único ponto em comum que existia entre a norma constitucional e o dispositivo da lei ordinária era o envolvimento do Poder Judiciário.

Todavia, a exigência constitucional era bem mais ampla, pois, a exceção ao sigilo não consistia, apenas, na autorização judicial, mas, também, na especificação das hipóteses e a forma como a escuta deveria ser realizada. Ora, esses requisitos não estavam previstos no mencionado artigo 57, da Lei $n^{\circ} 4.117 / 62$ e, por conseguinte, não houve a pretendida recepção pelo texto constitucional, razão porque a aplicabilidade deste teria que ser objeto de lei específica que disciplinasse a matéria.

Criada a discussão, mais cedo ou mais tarde, a mesma teria que bater às portas do Excelso Pretório, pois, a este, na qualidade de guardião da

\footnotetext{
${ }^{2}$ GRINOVER, Ada Pellegrini. Interceptações Telefônicas e Gravações Clandestinas no Processo Penal, em Novas Tendências do Direito Processual, Forense Universitária, Ed. 1990, págs. 60/80
} 
Carta Magna, competia o pronunciamento definitivo acerca do tema, tendo em vista que se estava diante de uma garantia de direito individual que poderia ser violado pelo Poder Público.

Caso concreto foi objeto de impetração de habeas corpus perante a Corte Suprema, onde se discutia a ilegalidade de escuta telefônica que resultou na efetivação de duas prisões em flagrante e na apreensão de substancial quantidade de entorpecente, escuta essa previamente autorizada pelo Judiciário e cuja transcrição de gravações veio a constar dos autos, como prova incriminadora, que redundou na condenação dos acusados.

Ressalte-se que a impetração da medida heróica foi contra decisão do Tribunal Regional Federal da $4^{\text {a }}$ Região que, seguindo a trilha do entendimento de outros Tribunais, havia considerado lícita a prova, fixando:

“O texto constitucional excepciona a vedação da prova colhida por escuta telefônica a realizada por ordem judicial, para investigação criminal ou instrução processual penal. Recepção do art. 57 do Código Brasileiro de Telecomunicações”. ${ }^{3}$

O Excelso Pretório, por maioria, embora indeferindo o habeas corpus, em face da sentença não se basear, exclusivamente, na degravação das escutas telefônicas, deixou patente que enquanto não houvesse lei que viabilizasse a quebra do sigilo, a prova obtida deveria ser tida como ilícita, constando da ementa do Acórdão, in verbis :

“Constitucional - Penal - Prova ilícita : “degravação” de escutas telefônicas - CF, art. 5 XII - Lei 4.117/62, art. 57, II, “e” - Habeas Corpus : exame da prova.

I - O sigilo das comunicações telefônicas poderá ser quebrado, por ordem judicial, nas hipóteses e na forma que a lei estabelecer para fins de investigação criminal ou instrução processual penal (CF, art. $5^{\circ}$, XII). Inexistência da lei que tornará viável a quebra do sigilo, dado que o inc. XII, do art. $5^{\circ}$ não recepcionou o art. 57, II, "e”, da Lei 4.117, de 1962, a dizer que não constitui violação de

\footnotetext{
${ }^{3}$ citado no HC no 69.912-0, do STF
} 
telecomunicações o conhecimento dado ao Juiz competente, mediante requisição ou intimação deste. É que a Constituição, no inc. XII do art. $5^{\circ}$, subordina a ressalva a uma ordem judicial, nas hipóteses e na forma estabelecida em lei.

II - No caso, a sentença ou acórdão impugnado não se baseia apenas na "degravação" das escutas telefônicas, não sendo possível, em sede de habeas corpus, descer ao exame da prova.

III - HC indeferido". ${ }^{4}(4)$

Quanto ao reconhecimento de que o texto constitucional exigia lei regulamentadora, os Ministros do Supremo Tribunal Federal praticamente não divergiram, merecendo destaque algumas afirmativas consignadas em votos proferidos.

O Ministro CARLOS VELLOSO, embora tenha negado a ordem, a esse propósito, foi taxativo :

\begin{abstract}
"Penso que o art. 57, II, e, da Lei 4.117/62, não estabelece que não constitui violação de telecomunicações o conhecimento dado ao Juiz competente, mediante requisição ou intimação deste, não é a lei que o referido inc. XII do art. $5^{\circ}$ exige para viabilizar a ressalva posta no mesmo inciso, ou seja, para admitir a quebra da inviolabilidade das comunicações telefônicas, por ordem judicial, nas hipóteses e na forma que a lei estabelecer para fins de investigação criminal ou instrução processual penal.

A Constituição, como vimos, subordina a ressalva a uma ordem judicial, nas hipóteses e na forma estabelecida em lei. A lei deverá estabelecer, portanto, a forma e as hipóteses; o art. 57, II, e, da mencionada Lei 4.117/62, não fixa a forma e tampouco as hipóteses; consequentemente, não houve a recepção do citado dispositivo legal pelo inc. XII do art. $5^{\circ}$ da Constituição”.
\end{abstract}

\title{
Na mesma esteira posicionou-se o Ministro CELSO DE MELLO :
}

“O art. 5, XII, da Lei Fundamental da República, permite, agora, a interceptação das conversas telefônicas. Essa providência excepcional sujeita-se, no entanto, para efeito de sua válida efetivação, a determinados requisitos que, fixados pelo próprio ordenamento constitucional, condicionam a eficácia jurídica desse meio de prova.

A derrogação desse princípio tutelar do sigilo telefônico somente legitimar-se-á, desde que a interceptação, sempre precedida de ordem judicial, venha a realizarse no campo exclusivo da persecução penal e nas hipóteses a serem ainda definidas em numerus clausus pelo legislador, a quem incumbe prescrever, de outro lado, o modo e a forma de sua execução.

\footnotetext{
${ }^{4}$ STF. HC no 69.912-0/RS, T. Pleno, Rel. Min. Sepúlveda Pertence, julg. 16.12.92, DJU 25.03.94
} 
O preceito constitucional em causa não se reveste, quanto à interceptação das conversações telefônicas, de densidade normativa suficiente. Ele impõe e reclama, para que possa válida e eficazmente atuar, a instauração de um processo de integração normativa de que derive a lei exigida pela Carta da República.

Nessa matéria, a só existência de ordem judicial - que não se ajuste às hipóteses ou não observe as formas estipuladas pela lei - não constitui elemento bastante para autorizar a escuta telefônica para fins de persecução penal.

O preceito inscrito no art. $5^{\circ}$, XII, da Lei Fundamental qualifica-se, no que se refere à escuta telefônica, como estrutura jurídica dotada de insuficiente densidade normativa, a tornar imprescindível, para que possa operar, a necessária mediação legislativa concretizadora do comando nele positivado. Na realidade, a norma constitucional em questão - por reclamar a interpositio legislatoris - não opera, em plenitude, no plano jurídico, e, no que concerne à possibilidade das interceptações telefônicas todas as suas consequências e virtualidades eficaciais.

Mas, o que mais centralizou a discussão foi a aceitação ou não da denominada prova ilícita por derivação, ou seja, a aplicação da doutrina que a jurisprudência americana denominou de princípios dos "fruits of the poisonous tree", ou, dentre nós, a doutrina dos “frutos da árvore envenenada”, a qual passou a ser adotada em casos em que haja a coleta de prova ilícita.

Neste particular, o Ministro SEPÚLVEDA PERTENCE sustentou que a doutrina da invalidade probatória do "fruit of the poisonous tree” é a "única capaz de dar eficácia à garantia constitucional da inadmissibilidade da prova ilícita”, afirmando, ainda :

"De fato, vedar que se possa trazer ao processo a própria "degravação" das conversas telefônicas, mas admitir que as informações nela colhidas possam ser aproveitadas pela autoridade, que agiu ilicitamente, para chegar a outras provas, que sem tais informações, não colheria, evidentemente, é estimular e, não, reprimir a atividade ilícita da escuta e da gravação clandestina de conversas privadas".

A esse propósito, também se manifestou o Ministro MARCO AURÉLIO que se pronunciou no sentido de que :

“... de grande importância, diz respeito à valia, à envergadura do que levantado mediante a quebra do sigilo das comunicações telefônicas, no que se chegou ao provimento judicial condenatório. Evidentemente não basta que se tenha o título condenatório como alicerçado, também, em outras provas. É preciso que se 
chegue à conclusão de que o exposto mediante a escuta clandestina não teve repercussão no convencimento do Estado-Juiz...”

Posteriormente, o Supremo Tribunal Federal voltou a pronunciar-se acerca do tema, também em caso que envolvia a apreensão de grande quantidade de cocaína, e do qual foi Relator o Ministro ILMAR GALVÃO, decidindo :

"Habeas Corpus. Acusação vazada em flagrante delito viabilizado exclusivamente por meio de operação de escuta telefônica, mediante autorização judicial. Prova ilícita. Ausência de legislação regulamentadora. Art. 5º XII, da Constituição Federal. Fruits of the poisonous tree. O Supremo Tribunal Federal, por maioria de votos, assentou entendimento no sentido de que sem a edição de lei definidora das hipóteses e da forma indicada no art. $5^{\circ}$, inc. XII, da Constituição, não pode o Juiz autorizar a interceptação de comunicação telefônica para fins de investigação criminal. Assentou, ainda, que a ilicitude da interceptação telefônica - à falta da lei que, nos termos do referido dispositivo, venha a discipliná-la e viabilizá-la - contamina outros elementos probatórios eventualmente coligidos, oriundos direta ou indiretamente, das informações obtidas na escuta. Habeas Corpus concedido". ${ }^{5}$

As decisões acima referidas mereceram aplauso doutrinário, sendo que CARLOS ALBERTO PIRES MENDES e FERNANDA VELLOSO TEIXEIRA afirmaram :

"Todavia, quer nos parecer que sem a devida regulamentação legal da matéria, não é possível que o Juiz faça as vezes do legislador e permita, ainda que com a melhor das intenções, a interceptação telefônica. Isto porque, enquanto não houver lei disciplinadora das formas das interceptações, bem como suas hipóteses de cabimento, não há base legal para que o Juiz autorize exceções, mesmo em se tratando do pior dos criminosos". ${ }^{6}$

Diante do posicionamento da jurisprudência e da doutrina, inadmitindo a escuta telefônica, sem a existência de lei que a disciplinasse, apesar dos vários projetos que tramitavam no Congresso Nacional, o Presidente da República enviou o Projeto de Lei $n^{\circ}$ 04/96, no qual o então

\footnotetext{
${ }^{5}$ STF. HC no 73.351-4/SP

${ }^{6}$ MENDES, Carlos Alberto Pires e TEIXEIRA, Fernanda Velloso, Boletim 41, do IBCCrim
} 
Ministro da Justiça NELSON JOBIM, salientava na Exposição de Motivos que a interceptação telefônica é “medida indispensável à investigação de certos crimes que vêm intranquilizando os habitantes das grandes cidades” e, por isso, torna-se imperiosa a edição de lei ordinária “ $a$ fim de aparelharem-se a policia e a Justiça para combate à criminalidade mais grave, de alta incidência, nos dias atuais”. Salientava, ainda, que o Projeto trazia normas especiais de investigação criminal para os crimes de roubo, extorsão, sequestro e extorsão mediante sequestro "dificultando a atuação isolada da família da vítima com afastamento da autoridade policial durante o desenrolar da trama criminosa”.

Da aprovação desse Projeto, que sofreu várias modificações, surgiu a Lei $\mathbf{n}^{0}$ 9.296, de 24 de julho de 1996, que não só dispõe sobre a quebra do sigilo e interceptação de comunicações telefônicas, mas, também, estabelece os casos em que ela não é admitida, bem assim a forma como a mesma deve ser procedida, além de conter dispositivo incriminador para aqueles que a violarem.

Com a existência da Lei ensaiaram-se alguns julgados sustentando que as interceptações realizadas antes de sua vigência poderiam ser utilizadas como prova, sendo que o Tribunal de Justiça de São Paulo, a esse respeito, ressaltou :

\footnotetext{
“Ocorre que com a sanção da Lei 9.296 de 24.07.96, estando a hipótese albergada na disposição complementar, não há falar-se em prova ilícita, mas em prova que, ilegitimamente obtida, tornou-se legitimada pela complementação da norma constitucional. E o que a Constituição veda é a prova ilícita, declarando-a inadmissível no processo (art. $5^{\circ}$, inciso LVI, da Constituição Federal) e não a prova ilegítima, que apenas tem relevância para eventual responsabilização penal da autoridade que a autorizou. Não tendo havido violação de direito material, já que a norma constitucional prevê a possibilidade da interceptação telefônica mediante autorização judicial, tal prova não pode ser tida como ilícita, mas apenas como não regulamentada, o que veio a ocorrer com a edição da Lei 9.296/96, sancionada pelo Senhor Presidente da República. Dessarte não há na
} 
hipótese direito adquirido a ver-se como ilícita a prova colhida, mas apenas questão de direito intertemporal a legitimá-la”. ${ }^{7}$

A primeira questão a ser abordada com relação ao julgado acima transcrito é traçar-se a distinção entre “prova ilícita” e “prova ilegítima”.

Os autores conceituam a prova ilícita como aquela "colhida infringindo-se normas ou princípios colocados pela Constituição e pelas leis, frequentemente para proteção das liberdades públicas e especialmente dos direitos de personalidade e daquela sua manifestação que é o direito à intimidade". Já a prova ilegítima "é aquela cuja colheita estaria ferindo normas de direito processual”.

LUIZ FLÁVIO GOMES, a propósito, afirma :

"Há forte corrente doutrinária, ademais, que afirma ser inadmissível no processo penal tanto a prova ilícita quanto a ilegítima. De qualquer modo, na interceptação telefônica autorizada antes da lei sob análise houve patente violação a direito material (constitucional, sobretudo, tendo em vista a tutela da intimidade e do sigilo das comunicações). Não se trata, simplesmente, de uma prova não regulamentada (embora isso já seja motivo suficiente para viciá-la irremediavelmente). Mais que isso : a autorização válida no direito brasileiro é exclusivamente a que atende criteriosamente a disciplina jurídica da Lei 9.296/96, que exige fundamentação específica, indicação do sujeito passivo, do motivo da interceptação etc.”. ${ }^{8}$

Confrontando-se os argumentos expostos no julgado em apreço com a posição doutrinária, parece fora de dúvida que todas as autorizações para interceptação telefônica emitidas antes da vigência da Lei 9.296/96, que regulamentou o inciso XII, configuram provas ilícitas e, por conseguinte, inadmissíveis no processo penal.

\footnotetext{
${ }^{7}$ TJ/SP. HC no 213.456-3-0, julg. 13.08.96

${ }^{8}$ GOMES, Luiz Flávio. Interceptação Telefônica, págs. 80/81
} 
Aliás, esse entendimento foi acolhido de modo seguro e incontroverso pela Suprema Corte, merecendo ser realçado votos proferidos pelo Ministro MARCO AURÉLIO :

“A teor do disposto no inciso XII do art. $5^{\circ}$ da Constituição Federal, de regra, o sigilo das comunicações telefônicas é inviolável. A exceção corre à conta de hipóteses e formas previstas em lei e mediante ordem judicial, visando à investigação criminal ou instrução processual penal. Ausência de regulamentação, à época do afastamento da inviolabilidade. Insubsistência de terse a ordem judicial como harmônica com a Carta Política da República... Não é auto-aplicável o inciso XII do artigo $5^{\circ}$ da Constituição Federal. Exsurge ilícita a prova produzida em período anterior à regulamentação do dispositivo constitucional". ${ }^{9}$

Assim, consolidou-se o entendimento de que as interceptações telefônicas, mesmo que autorizadas judicialmente, eram ilícitas e, por conseguinte, qualquer elemento probatório que delas derivasse, constituíase, também, em prova ilícita, em observância ao princípio dos frutos da árvore envenenada.

\footnotetext{
${ }^{9}$ STF. HC's 73.250-0 e 73.510-0
} 


\section{Capítulo IV - DA APLICAÇÃO DA LEI N 9.296/96}

Como salientado no início deste trabalho, a interceptação telefônica, nunca foi objeto no nosso ordenamento jurídico de um estatuto próprio, até porque as Constituições anteriores à de 1988 contemplavam a inviolabilidade do sigilo da correspondência e das comunicações telegráficas e telefônicas.

O fato é que a Constituição de 1988, como regra, continuou mantendo essa inviolabilidade, excepcionalizando-a, todavia, no que se refere às comunicações telefônicas, desde que a interceptação se efetivasse "por ordem judicial, nas hipóteses e na forma que a lei estabelecer para fins de investigação criminal ou instrução processual penal”.

Inobstante alguns projetos apresentados, dentre eles o coordenado pela Prof. ADA PELLEGRINI GRINOVER, o certo é que o que resultou na Lei $n^{\circ}$ 9.296/96 foi o enviado pelo Poder Executivo, o qual, embora tenha sofrido várias alterações, o texto aprovado tem sido objeto de muitas críticas doutrinárias e jurisprudenciais, mormente no que se refere aos abusos que teem sido cometidos, os quais chegaram, inclusive, ao próprio Poder Judiciário, como noticiou a Revista Veja, em sua edição de agosto de 2007, com a manchete : "Medo no Supremo. Ministros do STF reagem à suspeita de grampo na mais alta corte de Justiça do país".

Freqüentes teem sido as críticas aos abusos cometidos com a decretação de interceptações telefônicas, as quais teem sido utilizadas sem que, ao menos, haja a instauração de procedimento inquisitorial. Como bem disse o Ministro Marco Aurélio, tem-se procurado bisbilhotar a privacidade do cidadão para, depois, deflagrarem-se as apurações. 
A grande realidade é que as interceptações telefônicas acabaram por constituir-se na banalização das apurações, quando, deveriam apenas ser utilizadas em casos extremos, em situação que ficasse positivada a impossibilidade da apuração ou da instrução sem a utilização das mesmas.

Na grande maioria dos casos, a autoridade policial, antes que efetive qualquer diligência, representa pela decretação da quebra do sigilo telefônico, valendo-se de afirmativas genéricas e o seu pedido acaba sendo endossado pelo Ministério Público e deferido pela autoridade judiciária.

A partir daí renovações vão sucedendo-se por meses e até mesmo anos para, depois, única e exclusivamente em razão das conversações telefônicas interceptadas, ser deflagrada a denominada “operação”, que resulta no cumprimento de buscas e apreensões e na efetivação de prisões daqueles que eram meros investigados.

Ora, se nada havia sido investigado, se inexiste indiciamento e se o agente, sequer, foi ouvido pela autoridade policial, como saber-se se a prova poderia ou não ser colhida por outros meios?

Casos existem em que, antes da efetivação das medidas de busca e apreensão e da prisão dos investigados e sua oitiva, o Ministério Público já tem elaborada a denúncia, ancorado, apenas, no teor das degravações que lhe são repassadas pela autoridade policial.

Os excessos teem sido de tal ordem que uma mera denúncia anônima tem sido utilizada como elemento único para a decretação da quebra do sigilo das interceptações telefônicas, o que, como não poderia deixar de ser, vem sendo repudiado pela jurisprudência. 
O Tribunal Regional Federal da $1^{\mathrm{a}}$ Região, em acórdão da lavra do Desembargador Federal TOURINHO NETO, assim decidiu :

“PROCESSO PENAL. INTERCEPTAÇÃO TELEFÔNICA. MEIO
PROBATÓRIO DRÁSTICO. PRINCİPIO DA NECESSIDADE.
INTERVENÇÃO MÍNIMA. MEIO CÔMODO E FÁCIL DE INVESTIGAÇÃO.
INTERCEPTAÇÃO DE PROSPECÇÃO.
I - Não se pode admitir a interceptação telefônica quando a prova pode ser feita
por outros meios disponíveis, outros meios legais processuais (Lei no 9.296, de
24/07/1996, art. 20, II). É necessário, pois, que a interceptação telefônica seja
indisponível. Conditio sine qua non para a apuração do crime. Não pode haver,
como diz Zaffaroni, generosidade nas autorizaçôes de escuta telefônica. Para
tentar localizar o indiciado, no caso sub judice, a autoridade policial pede a
quebra do sigilo de 17 (dezessete) terminais telefônicos de diversas pessoas para
quem o indiciado provavelmente telefonou!
II - É bom frisar que a interceptação telefônica não pode ser determinada para
apurar se o cidadão, contra o qual inexiste qualquer indício, só mera suspeita, está
ou não cometendo algum crime. É vedada a interceptação de prospecção.”

Em matéria divulgada pelo CONJUR, sob o título "Investigação Sentada - MP-SP explica como funcionam (mal) as interceptações”, é citado um documento de 18 páginas, timbrado pelo Grupo de Atuação Especial de Controle Externo da Atividade Policial, no qual é dito que " $\boldsymbol{a}$ polícia obtém autorizações judiciais para grampos praticamente enganando os magistrados: ora fornecendo dados falsos $e$ incompletos sobre os investigados, ora promovendo escutas sem existência de inquérito policial".

Nesse mesmo documento, os seus signatários chamam esse procedimento de "investigação sentada", porque, para eles, "a concessão de autorizações judiciais para quebra de sigilo telefônico como instrumento de investigação "passou a alimentar a lei do menor esforço e tem sido aplicada antes de se esgotarem ou de se aplicarem em concomitância os recursos regulares, como a investigação propriamente

\footnotetext{
${ }^{10}$ TRF-1 ${ }^{\text {a }}$. Reg. AC n ${ }^{\circ}$ 2005.38.00.032154?MG, Rel. Des. Fed. Tourinho Neto
} 
dita. Muitas vezes, inclusive, é usada até como único método de investigação”.

Portanto, o que nos parece certo é que a vontade do legislador, ao abrir a exceção para as interceptações telefônicas, não foi, de modo algum, abolir as apurações através de inquérito policial ou instrução processual, mas, permitir que as mesmas, por não poderem ser feitas por outros meios, virem a ser complementadas mediante a decretação da medida excepcional.

Antes de serem examinados os dispositivos da Lei $n^{0} 9.296 / 96$, deve ser destacado que o artigo $1^{0}$ refere-se a "interceptação de comunicações telefônicas”, abrangendo não só a interceptação propriamente dita, que é a captação feita por um terceiro de uma comunicação telefônica alheia, sem o conhecimento dos comunicadores, como, também, a escuta, que consiste na captação realizada por um terceiro de uma comunicação alheia, mas com o conhecimento de um dos comunicadores.

Segundo LUIZ FLÁVIO GOMES, na prática, ambas as situações podem verificar-se, pois, “pode o Juiz autorizar uma "interceptação” para descobrir prova num caso de tráfico de entorpecentes (...) como pode permitir uma “escuta” num caso de seqüestro em que a família da vítima, obviamente, está sabendo da captação da comunicação”.

Não se deve, ainda, confundir interceptação e escuta com "gravação telefônica”, eis que esta é a captação feita diretamente por um dos comunicadores.

Outra questão a ser abordada é a relativa aos “dados” telefônicos, ou seja, os registros constantes na operadora telefônica, tais como : data da 
chamada, horário, número do telefone chamado, duração do uso, valor da chamada. A quebra desse sigilo tem amparo na Lei n ${ }^{\circ}$ 9.296/96 ?

O tema é controverso, pois, para VICENTE GRECO FILHO o sigilo, neste aspecto, pode ser quebrado em face da aplicação da lei em apreço, mas, LUIZ FLÁVIO GOMES diverge desse entendimento, considerando que a lei fala em "comunicações telefônicas” e estas não podem abranger os registros telefônicos.

De qualquer modo, entende este último autor que, por ordem judicial e observado o princípio da proporcionalidade, pode ser quebrado o sigilo dos dados telefônicos para fins de investigação criminal ou instrução processual penal.

Antes da vigência da Lei no 9.296/96, em vários processos criminais, foram requisitados registros telefônicos e, ao que se saiba, não foi questionada a sua licitude, uma vez que as requisições emanaram de ordem judicial. 


\section{Capítulo V - CONSIDERAÇÕES SOBRE ALGUMAS DAS NORMAS DA LEI N $9.296 / 96$}

Preceitua o art. $1^{\circ}$, da Lei $n^{\circ} 9.296 / 96$ :

\footnotetext{
“A interceptação de comunicações telefônicas, de qualquer natureza para prova em investigação criminal e em instrução processual penal, observará o disposto nesta Lei e dependerá de ordem do juiz competente da ação principal, sob segredo de justiça”.
}

A norma transcrita estabelece que a interceptação de comunicações telefônicas destina-se à produção de prova em investigação e em instrução processual penal, deve observar as disposições da Lei, sendo que a sua decretação dependerá de ordem do juiz com competência para processar e julgar a ação principal, enquanto que sua operacionalização será em segredo de justiça.

\section{1 - Da destinação da interceptação}

A primeira questão a ser abordada diz respeito à destinação da interceptação, ou seja, a lei diz que a prova dela originária é para ser usada em investigação ou instrução processual penal. Daí indagar-se : pode haver interceptação sem investigação ou instrução processual penal ? A resposta parece-nos negativa.

Muito embora alguns autores entendam que a investigação criminal não deve ser confundida com inquérito policial instaurado, não há divergência de que a interceptação somente é admissível no curso de uma apuração. Se não houver investigação criminal, torna-se impossível o atendimento de outras exigências da lei, notadamente, a demonstração da impossibilidade da prova ser produzida por outros meios, como, também, a menção dos indícios razoáveis da autoria ou participação. 
Segundo cremos e à luz do que dispõe o Código de Processo Penal, a investigação é o conjunto de elementos probatórios ou indiciários colhidos no curso do inquérito policial, visando a apuração de infrações penais e sua autoria (art. $4^{\circ}$ ). É certo que o inquérito pode ser instaurado fora do âmbito da policia judiciária, mas, de qualquer modo, a sua finalidade será sempre a de reunir provas ou indícios que permitam a instauração de ação penal.

Além do mais, numa interpretação sistemática, verifica-se que a Lei $n^{\circ}$ 9.296/96, em vários dispositivos, envolve a autoridade policial na medida, como é o caso da formulação do requerimento (art. $3^{\circ}$, II), a condução do procedimento da interceptação (art. $6^{\circ}$ ), o encaminhamento de seu resultado (art. $6^{\circ}, \S 2^{\circ}$ ) e a requisição de serviços e técnicos especializados às concessionárias de serviço público (art. $7^{\circ}$ ).

Dentro desse contexto, o melhor entendimento doutrinário é no sentido de que a interceptação não pode ser deferida para dar início à investigação criminal e, assim, é esta imprescindível para que possa a medida excepcional ser decretada.

Já no que se refere à interceptação durante a fase de instrução processual penal, a única exigência que se faz é a positivação de que a prova não pode ser produzida por outro meio menos invasivo da intimidade, pois, os indícios razoáveis de autoria ou participação já foram atendidos, tanto que a ação penal foi instaurada.

\section{2 - Do juiz competente para decretar a interceptação}

No que tange à “ordem do juiz competente da ação principal”, parece induvidoso que a autorização só poderá ser dada por juiz dotado de 
jurisdição penal, pois, a interceptação constituir-se-á em "prova em investigação criminal e em instrução processual penal”.

Quando a interceptação for decretada no curso da instrução criminal, é evidente que o juiz da ação principal já está determinado. Mas, quando a medida ocorrer na fase de "investigação criminal", predomina o entendimento sustentado por SCARANCE FERNANDES de que "em comarcas com vários juízes criminais poderá haver necessidade de distribuição do requerimento em que se pede a interceptação, ficando prevento o juiz que a autorizar para futura ação penal”, como, aliás, preceitua o art. 83, do Código de Processo Penal.

Fora do horário de expediente do Judiciário é feito plantão, sendo que o juiz que nele atua dispõe de competência para decidir todo e qualquer feito que seja levado à sua apreciação, inclusive, os criminais urgentes. Todavia, concluído o plantão, deve ser procedida à livre distribuição.

Em realidade, a previsão legal em exame nada mais representa do que a observância ao princípio constitucional do juiz natural, de modo a evitar que alguém possa ser processado e julgado por juiz de exceção.

\section{3 - Da preservação do segredo de justiça}

Segundo LUIZ FLÁVIO GOMES, três são os momentos em que deve ser preservado o segredo de justiça quanto às interceptações telefônicas.

No primeiro, de âmbito interno, quando estão sendo realizadas as diligências, gravações e transcrições, as interceptações devem processar-se sob segredo absoluto, só podendo ter acesso às mesmas as pessoas envolvidas na sua operacionalização; num segundo momento, o segredo, 
embora continue interno, é parcial, pois, desde que formalizadas as diligências, delas pode tomar conhecimento o investigado; e, num terceiro momento, mesmo depois de afastado o segredo em relação ao investigado, não pode o seu conteúdo ser liberado para qualquer pessoa.

É mais do que razoável que o segredo, num primeiro momento, tenha como destinatários o investigado e seu defensor, acaso já o tenha constituído. Entretanto, recebidos os autos apartados da autoridade policial, o juiz, de acordo com o $\S 3^{\circ}$, do art. $6^{\circ}$, deve determinar a providência prevista no art. 80, que é a "preservação do sigilo das diligências, gravações e transcrições respectivas”.

Pois bem. Pouco importando se a interceptação foi determinada durante a investigação ou no curso da instrução processual, concluídas as diligências, gravações e transcrições, deve ser levantado o segredo de justiça com relação ao investigado e seu defensor, facultando-lhe pleno acesso à prova, de sorte a que lhe seja permitida a preparação do contraditório e, sobretudo, o exercício da ampla defesa.

Nesse sentido posicionou-se o Supremo Tribunal Federal, ao editar a Súmula Vinculante $\mathrm{n}^{\circ} 14$, do seguinte teor :

"É direito do defensor, no interesse do representado, ter acesso amplo aos elementos de prova que, já documentados em procedimento investigatório realizado pelo órgão com competência de policia judiciária, digam respeito ao exercício do direito de defesa”.

Mas, a cessação do segredo de justiça para as partes envolvidas no processo não deveria ocasionar que as interceptações fossem disponibilizadas para terceiros, sobretudo, para a mídia.

Tem sido uma constância que, após as pirotécnicas operações levadas a efeito pelos órgãos policiais, no mesmo dia, sejam reproduzidos 
trechos de conversações telefônicas, o que, evidentemente, está em absoluta desconformidade com o texto legal.

Não se pode perder de vista, nunca e jamais, que a interceptação é uma medida excepcional, que atinge a privacidade do cidadão e, por isso, entregar o seu conteúdo à imprensa é vilipendiar os seus direitos, gerando, desde logo, presunção de culpabilidade.

Quantos foram os casos em que pessoas foram expostas à execração pública e, depois, reconhecida pelo Judiciário a sua inocência. Veja-se a Escola de Base, em São Paulo e outros mais de que se tem notícia.

A esse propósito, calha mencionar trecho do voto proferido pelo Des. Fed. TOURINHO FILHO, quando S. Exa. destacou :

“As gravações legais de conversas telefônicas valem, em princípio, como prova criminal e têm sido cada vez mais utilizadas pelas autoridades policiais nas investigações.

A evolução da tecnologia favorece a investigação. Os equipamentos disponíveis hoje em dia têm capacidade de vigiar maior número de linhas, dando, no entanto, também lugar a abusos e, conseqüentemente, à prática de crimes, como o previsto no art. 10 da Lei $n^{\circ}$ 9.296, de 24.07.1996, que regulamenta o inciso XII, parte final, do art. $5^{\circ}$ da Constituição Federal; no art. $4^{\circ}$, "h", que regula o direito de representação e o processo de responsabilidade administrativa, civil e penal, nos casos de abuso de autoridade.

Os vazamentos das interceptações, a maioria das vezes pela própria Policia (algumas vezes pelo Ministério Público e outras por juízes), propiciando que, praticamente de modo imediato, os meios de comunicação tenham conhecimento dos diálogos, possibilitando que as televisões os reproduzam, de maneira fria e insossa e muitas vezes incompleta, retiradas de um texto que tendo um outro significado.

Os vazamentos, como as prisões holywoodianas, algemas utilizadas desnecessariamente em homens sem antecedentes criminais, não deixam de ser ameaça aos direitos constitucionais do cidadão.

Esses abusos levaram o eminente Ministro GILMAR MENDES, do Supremo Tribunal Federal, reconhecido conhecedor profundo do direito constitucional, a classificar como "canalhice" a inclusão de seu nome numa lista de suspeitos vazada pela Policia Federal. Segundo o ilustre Ministro, embora soubesse de que se tratava de um homônimo, a policia fez o vazamento de propósito, para manifestar descontentamento em relação aos habeas-corpus concedidos pelo STF a alguns presos pela Operação Navalha. 
$(\ldots){ }^{11}$

O certo é que, inobstante sejam reiterados esses procedimentos ilegais e tipificarem eles crime definido no art. 10, da Lei $n^{\circ}$ 9.296/96, punido com pena de reclusão de 2 a 4 anos, não se tem notícia de que alguém tenha sido processado pela prática dessa ilicitude.

\section{4 - Sem indícios razoáveis de autoria ou participação em delito não se admite interceptação das comunicações telefônicas}

Preceitua o art. $2^{\circ}$ :

“Não será admitida a interceptação de comunicações telefônicas quando ocorrer qualquer das seguintes hipóteses :

I - não houver indícios razoáveis da autoria ou participação em infração penal”.

Dentre os projetos que tramitaram pelo Congresso Nacional, o de $\mathrm{n}^{\circ}$ 35/14 previa quais os crimes que autorizavam a interceptação : terrorismo, tráfico de substâncias entorpecentes e drogas afins, tráfico de mulheres e subtração de incapazes, quadrilha ou bando, crimes contra a ordem econômica e financeira, falsificação de moedas, extorsão simples e extorsão mediante seqüestro, contrabando, homicídio qualificado, roubo seguido de morte, ameaça ou injúria cometida por telefone e outros decorrentes de organização criminosa.

Entretanto, o legislador, ao invés de seguir a indicação dos crimes, preferiu apontar os casos em que as interceptações telefônicas são inadmissíveis.

O primeiro desses casos é quando "não houver indícios razoáveis da autoria ou participação em infração penal”.

\footnotetext{
${ }^{11}$ TRF-1 $^{\text {a }}$. Reg. MS no 2004.01.00.059657-6/GO
} 
Sob certo aspecto, o requisito em questão mostra-se desnecessário, tendo em vista a natureza cautelar e excepcional da medida, em face do que teem que existir motivos justificadores da interceptação, notadamente, no que se refere à autoria ou participação, pois, do contrário, ela não pode ser autorizada pelo juiz.

Portanto, seja na representação como na decisão duas condições mostram-se imprescindíveis : a demonstração da prática de crime e indícios que apontem a autoria ou participação.

A propósito é valido que, mais uma vez, utilizemos a lição de LUIZ FLÁVIO GOMES :

“... a probabilidade de existência de uma infração penal, por sua vez, deve estar amparada em provas inequívocas a respeito da materialidade (existência concreta e real de um acontecimento). Não são o bastante "fatos duvidosos", meras possibilidades ou conjecturas. Somente fatos induvidosos permitem o juízo de probabilidade, indispensável para a decretação da interceptação telefônica”. ${ }^{12}$

Por isso mesmo é que entendemos que o requisito em exame fica por demais difícil de ser comprovado sem que haja a prévia instauração de investigação criminal, pois, será em razão desta que podem exsurgir os indícios de autoria.

\section{5 - Só a impossibilidade da prova ser feita por outros meios permite a interceptação}

“II - a prova puder ser feita por outros meios disponíveis”.

Como demasiadamente salientado, a regra constitucional é a preservação da intimidade, pelo que não será aceitável impor-se a

\footnotetext{
${ }^{12}$ GOMES, Luiz Flávio. Ob. Cit
} 
excepcionalidade, que é medida extremada, quando a prova puder ser obtida por outros meios, ou seja, houver a possibilidade de alcançar-se o mesmo resultado por meios probatórios menos drásticos e devassadores que a interceptação.

As interceptações telefônicas não podem e não devem ser banalizadas e, muito menos, utilizadas como lei do menor esforço na busca de caminhos mais fáceis para suprir a investigação.

Tem sido comum que autoridades policiais, mediante a simples afirmativa de que não possuem meios para investigar, representem pela decretação da interceptação. Ora, essa não é e nem pode ser a finalidade da lei. Para que a medida seja requerida e decretada, deve ser demonstrado, de forma objetiva, a ilicitude praticada pelo agente e, sobretudo, a impossibilidade de se colher elementos probatórios que o possam incriminar sem que seja através da medida cautelar de interceptação.

Nossos tribunais teem sido rigorosos quanto à exigência deste e de outros requisitos legais, motivo pelo qual são freqüentes decisões como a que se transcreve:

“Lei de interceptação da comunicação telefônica. Indícios razoáveis da autoria ou
participação em infração penal. Se prova puder ser feita por outros meios
disponíveis. Prova ilícita. Inutilização de gravação. Desentranhamento das
gravações e das degravações dos autos.
O Poder Constituinte Originário resguardou o sigilo das comunicações
telefônicas, erigindo-o à categoria de garantia individual, prevista no art. $5^{\circ}$,
inciso XII, da Constituição Federal, admitindo, de forma excepcional, a sua
flexibilidade, nos termos da Lei n. 9.296/96, para fins de investigação criminal ou
instrução processual penal. Além da necessidade do ilícito em apuração ser
apenado com reclusão, o legislador ordinário estabeleceu ainda como critérios
para a utilização da interceptação telefônica, a contrario sensu, a existência de
indícios acerca da autoria ou participação na infração penal, bem como a
demonstração de inviabilidade de produção da prova por outros meios.
Demonstrado, in casu, que a representação pela quebra do sigilo telefônico dos
pacientes foi deferida antes mesmo dos sócios da empresa investigada terem sido
ouvidos pela autoridade policial, tratando-se de medida primeva em busca de
provas acerca da autoria do ilícito, imperioso o reconhecimento da ilegalidade da
medida. Ordem concedida para declarar a nulidade do despacho que atendeu a 
representação feita pela autoridade policial, determinando-se a inutilização do material colhido, nos termos do artigo $9^{\circ}$ da Lei n. 9.296/96, devendo as instâncias ordinárias absterem-se de fazer qualquer referência às informações obtidas pelo meio invalidado”. ${ }^{13}$

Nesse mesmo sentido é a lição de ADA PELLEGRINI GRINOVER, ANTONIO SCARANCE FERNANDES e ANTONIO MAGALHÃES GOMES FILHO :

\begin{abstract}
"A lei ainda firma o critério da estrita necessidade (não poder a prova ser feita por outros meios disponíveis : inc. II do art. $2^{\circ}$ ). E no art. $4^{\circ}$ repisa que o pedido de interceptação conterá a demonstração de sua necessidade para a apuração de infração penal.

É que tais interceptações representam não apenas poderoso instrumento, freqüentemente insubstituível, no combate aos crimes mais graves, mas também uma insidiosa ingerência na intimidade não só do suspeito ou acusado, mas até de terceiros, pelo que só devem ser utilizadas como ultima ratio.

Desse modo, se o juiz autorizar a interceptação, será ilícita se presentes outros meios pelos quais a prova possa ser feita". ${ }^{14}$
\end{abstract}

Ao que nos parece, o posicionamento jurisprudencial e doutrinário mostra-se de todo acertado, pois, do contrário, a grande maioria dos delitos não precisaria de qualquer apuração. Bastaria a interceptação de conversações telefônicas, remetê-las a Juízo e, com base nas mesmas, simplesmente prolatar sentença.

Com toda a certeza, a vontade do legislador, ao abrir a exceção para as interceptações telefônicas, não foi, de modo algum, abolir as apurações através de inquérito policial ou instrução processual, mas, permitir que as mesmas, por não poderem ser feitas por outros meios, virem a ser complementadas mediante a decretação da medida excepcional.

\footnotetext{
${ }^{13}$ STJ. $5^{\mathrm{a}}$. Turma, HC no 128.087, Rel. Min. Jorge Mussi, julg. 27.10.2009, DJe 14.12.2009

${ }^{14}$ GRINOVER, Ada Pellegrini e Outros. As Nulidades no Processo Penal, 10a . ed. rev., atual. e ampl., São Paulo, Rev. dos Tribunais, 2007, pág. 219
} 


\section{6 - Infração penal punida com detenção não autoriza a interceptação}

"III - o fato investigado constituir infração penal punida, no máximo, com pena de detenção".

Como visto no Capítulo II, a legislação portuguesa somente admite a interceptação das comunicações telefônicas quando o crime investigado é punível com pena de prisão superior, no máximo, a três anos. Do mesmo modo estabelece a legislação italiana, que só permite a medida quando a pena cominada seja de reclusão e superior a cinco anos.

Entretanto, pelo preceito acima transcrito, as interceptações somente são inadmissíveis quando o fato objeto da investigação estabelecer sanção, no máximo, punida com detenção.

O dispositivo em questão tem sido objeto de críticas doutrinárias, por entenderem alguns autores que ele ofende o princípio da proporcionalidade, sendo que outros chegam a considerá-lo inconstitucional.

De fato, quando a Lei $n^{0}$ 9.296/96 foi sancionada já estava em vigor a Lei n ${ }^{0}$ 9.099/95, a qual, em seu art. 89, admite a suspensão condicional do processo quando a pena mínima não for superior a um ano.

Assim, inúmeras são as infrações penais que, mesmo estabelecendo pena de reclusão, não geram cumprimento obrigatório de pena, pelo que não parece razoável que para a apuração das mesmas possa ser invadida a intimidade do agente incriminado.

Levando em consideração a excepcionalidade da medida, melhor seria que o legislador elencasse quais os delitos que a admitiam ou, então, afastar a sua decretação nos casos de pequeno ou médio potencial ofensivo, 
para os quais o processo pudesse ficar suspenso ou a pena ser substituída por restrição de direitos.

\title{
4.7 - A decisão que decreta a interceptação terá que ser devidamente fundamentada
}

\begin{abstract}
"É inquestionável que a exigência da fundamentação das decisões judiciais, mais do que expressiva imposição consagrada e positivada pelo nova ordem constitucional (art. 93, IX), reflete uma poderosa garantia contra eventuais excessos do Estado-Juiz, pois, ao torná-la elemento imprescindível $e$ essencial dos atos sentenciais, quis o ordenamento jurídico erigi-la como fator de limitação dos poderes deferidos aos magistrados e Tribunais”. 15
\end{abstract}

É imperativo constitucional previsto no art. 93, inciso IX, que todas as decisões judiciais sejam devidamente fundamentadas, sob pena de nulidade. Ora, se a Carta Magna exige que todas as decisões sejam fundamentadas, o que dizer-se, então, daquelas que se constituem em medidas excepcionais e que atingem a intimidade do cidadão ?

A resposta não pode ser outra que não seja a evidente nulidade das mesmas, pois, é inadmissível que uma garantia constitucional seja excepcionada sem que a decisão que a impõe esteja devidamente fundamentada.

LUIZ FLÁVIO GOMES e RAUL CERVINI, tratando do tema ora enfocado, salientam:

\footnotetext{
${ }^{15}$ STF. HC nº 68.202-2, Rel. Min. Celso de Mello, DJU 15.03.91, pág. 2647
} 
“Justifica-se a exigência legal de fundamentação (embora nesse ponto, reconheçase, a lei apenas repetiu o que já está na CF, art.93, IX), por várias razões: em primeiro lugar, não se pode esquecer que a interceptação telefônica é medida cautelar inaudita altera pars, logo a existência de fundamentação não pode ser encarada efetivamente como pura formalidade, senão como requisito essencial para a salvaguarda do direito à intimidade; o Juiz deve ser rigoroso no exame dos pressupostos e requisitos da interceptação porque é o único controlador da devassa; esse controle deve ser efetivo, real, porque feito por quem goza de independência frente aos órgãos da persecutio criminis; urge a observância da legalidade estrita porque a quebra do sigilo é medida excepcional e restritiva de um direito fundamental; a motivação, por tudo isso, deve ser exaustiva, razoável, convincente, ponderada, proporcional.” 16

E, prosseguindo, ainda afirmam os renomados autores:

"Diante de tudo que foi exposto, resulta bastante evidente que o Juiz, no momento de motivar sua decisão, não pode simplesmente repetir as palavras da lei, não pode exteriorizar uma motivação genérica, materializando-a principalmente em modestos impressos, com expressões vagas e pouco significativas para o caso concreto. Urge o exame exaustivo dos pressupostos fáticos e jurídicos da interceptação. Do contrário, será nula a decisão.”

Na mesma esteira é o posicionamento da jurisprudência de nossos tribunais :

“É inadmissível, no Processo Penal, a utilização de provas obtidas por meios ilícitos para embasar a persecução penal ou uma eventual condenação (art. 5, LVI da CF). Reconhecida a ilicitude da prova pelo próprio Tribunal a quo, ante a falta de fundamentação das decisões de prorrogação da medida de interceptação telefônica do acusado, a única solução possível é a sua total desconsideração pelo Juízo processante e o desentranhamento do processo das transcrições dessas interceptações consideradas ilegais, como consectário lógico e necessário de reconhecimento de ser ilícita a prova colhida ao abrigo de decisões judiciais não fundamentadas, como assentou o egrégio TRF da $4^{\mathrm{a}}$. Região. Ordem concedida, para determinar a exclusão do processo das provas obtidas por meio das prorrogações das interceptações telefônicas”. ${ }^{17}$

\section{Concedendo medida liminar no HC 159.159, o Ministro CESAR}

\section{ASFOR ROCHA, a respeito do tema afirmou :}

\footnotetext{
${ }^{16}$ GOMES, Luiz Flávio e CERVINI, Raul, Ob. Cit., págs. 214/215

17 STJ. 5a. Turma, HC 143.697, Rel. Min. Napoleão Nunes Maia, julg. 22.09.2009, DJe 13.10.2009
} 
"Noutro viés, a teor do art. 93, IX, da Constituição, é de curial sabença que a fundamentação é requisito de validade de qualquer decisão judicial.

Ora, com muito maior razão há de se ver que terá de ser ainda mais fortemente fundamentada a decisão que excepciona, anula e afasta os sigilos assegurados na Carta Magna, que decorrem de conquistas civilizatórias, por isso mesmo que é diretriz uniforme da jurisprudência das Cortes e das lições da doutrina jurídica a sua exigência impostergável a não tolerar que o afastamento daquelas garantias se faça de modo banal ou simples, calcada, apenas, por exemplo, na comodidade da coleta de indícios ou produção de provas. Assim é que se requer, como anotam os impetrantes, que a quebra do sigilo telefônico só se dê por decisão exaustivamente fundamentada e individualizada”.

Assim, tanto a doutrina como a jurisprudência de nossos Tribunais exigem que as decisões judiciais, sejam elas de que natureza for, devem ser devidamente fundamentadas, sob pena de serem consideradas nulas, como bem salienta a professora ADA PELLEGRINI GRINOVER, quando afirma : “assim como é insanavelmente viciado o processo que não respeite as garantias do “devido processo legal”, também o é a sentença cuja motivação seja deficiente, exatamente na medida em que a obrigação de motivar decorre das mesmas garantias”.

\section{8 - Do prazo de duração das interceptações}

O prazo das interceptações telefônicas foi objeto de extensa discussão no Congresso Nacional, havendo quem entendesse que, desde que permanecessem os pressupostos para a concessão inicial da medida, esta poderia ser renovada em períodos iguais e sucessivos, indeterminadamente, como previa o projeto do Deputado Miro Teixeira.

Todavia, essa questão relativa ao prazo veio a ser definida nos termos previstos no texto definitivo, que o limita em 15 (quinze) dias, renovável por igual período, sendo que o relator do projeto - Deputado Federal José Genuíno -, ao apreciar a emenda do Senado, que pretendia estabelecer prazo indeterminado para a interceptação, ressaltou : 


\begin{abstract}
“A Emenda n. ${ }^{\circ} 4$ (que altera o artigo $5^{\circ}$ ) visa a proporcionar um tempo mais amplo a escuta, o que parece-nos não deva ser adotado. Lembrando que o tema já foi amplamente discutido na Comissão quando da votação do projeto original, tem-se que é necessário pôr termo final à escuta. Possibilitar que ela pudesse ser indefinidamente renovada seria permitir ao Poder Judiciário imiscuir-se na intimidade das pessoas, o que só se pode admitir por exceção. Se for regra, certamente haverá o óbice inarredável da inconstitucionalidade, o que recomenda a rejeição da emenda.”
\end{abstract}

Vê-se, pois, que a questão relativa ao prazo da interceptação telefônica não se prende à apuração do legislador, mas, à expressa determinação do mesmo que, de forma deliberada e definitiva, limitou a escuta em 15 (quinze) dias, prorrogáveis por igual período conforme taxativamente está previsto no artigo $5^{\circ}$, da Lei em exame.

Há de se admitir que essa mesma discussão também existiu no campo doutrinário, como foi demonstrado em excelente artigo de autoria de EDUARDO LUIZ SANTOS CABETTE, sob o título “O prazo de duração da interceptação telefônica e sua renovação”. ${ }^{18}$

Demonstra esse jurista que o posicionamento doutrinário tem se mostrado discrepante, salientando que Luiz Flávio Gomes, in “Interceptações Telefônicas”, págs. 218/219, menciona que PAULO NAPOLEÃO QUEZADO, CLARISIER CAVALCANTE e ALTAMIRO LIMA FILHO, entendem que “a renovação só pode ocorrer uma vez”, enquanto que Damásio E. de Jesus, Vicente Greco Filho e Antonio Scarance Fernandes entendem que "não há limite” às renovações, tudo dependendo da demonstração in casu da necessidade $e$ indispensabilidade da medida, dentro da proporcionalidade a ser aferida pelo "prudente arbítrio do juiz”.

${ }^{18}$ IBCCrim n $^{\circ} 70$, setembro/98 
Todavia, o articulista, ao exteriorizar o seu entendimento, discorda daqueles que não vêem limites para as renovações, por considerar que "a possibilidade de renovações indeterminadas seria conceder uma "carta branca” ao magistrado para uma contínua intromissão na esfera privada das comunicações telefônicas das pessoas, para fins de investigação criminal”.

Esse mesmo autor ainda destaca :

"Já de muito tempo remonta a lição de BECCARIA de que "cabe exclusivamente às leis fixar o espaço de tempo que se deve empregar para a investigação das provas do delito, e o que se deve conceder ao acusado para sua defesa. Se o juiz tivesse esse direito estaria exercendo as funções de legislador”.

E prossegue :

"O entendimento quanto à possibilidade de renovação ao arbítrio do juiz, conduziria à mesma conclusão nos casos da prisão temporária previstos no art. $2^{\circ}$ da Lei $\mathrm{n}^{\circ} 7.960 / 89$ e no art. $2^{\circ}$, $\S 3^{\circ}$, da Lei ${ }^{\circ}$ 8.072/90, fato este plenamente inadmissível à consciência geral, mas que, em essência, não diverge do caso das interceptações. A redação dos dispositivos é bastante semelhante e os argumentos expedidos para a defesa de reiterações indeterminadas da interceptação teriam pleno cabimento, sob a alegação de que sempre que fosse comprovada a "extrema necessidade" para as investigações, poder-se-ia renovar o prazo de restrição da liberdade”.

Finaliza afirmando :

"Portanto, a conclusão em relação à renovação das interceptações somente pode ser ponderada no sentido da possibilidade de uma única reiteração pelo período de 15 dias, totalizando o tempo máximo de 30 dias de intromissão insidiosa na esfera do sigilo das comunicações do indivíduo”.

Há de se admitir, também, que a jurisprudência de nossos Tribunais, notadamente do Egrégio Superior Tribunal de Justiça, vinha interpretando de forma mais extensiva a norma em questão. Entretanto, em face dos constantes abusos cometidos quanto à aplicabilidade dessa medida de 
exceção, inclusive envolvendo órgãos não policiais na execução da mesma, atingindo até mesmo a Corte Suprema, o Tribunal Cidadão, passou a rever seu posicionamento anterior, para estabelecer que a interceptação telefônica somente será passível de uma única renovação, reputando nula a escuta produzida em período superior, conforme decisão da qual foi relator o Ministro Nilson Naves :

\begin{abstract}
“INTERCEPTAÇÃO TELEFÔNICA. AUTORIZA- ÇÕES SUCESSIVAS. Trata-se de habeas corpus em que se pugna pela nulidade $a b$ initio do processo penal, visto que sua instauração deu-se com base em provas ilícitas, ou seja, decorrentes de interceptação telefônica cuja autorização foi sucessivamente renovada e os investigados, ora pacientes, foram assim monitorados por um prazo superior a dois anos. A Turma entendeu que, no caso, houve sim violação do princípio da razoabilidade, uma vez que a Lei n. 9.296/1996, no seu art. $5^{\circ}$, prevê o prazo de 15 dias para a interceptação telefônica, renovável por mais 15 , caso seja comprovada a indispensabilidade desse meio de prova. Assim, mesmo que fosse o caso de não haver explícita ou implícita violação desse dispositivo legal, não é razoável que a referida interceptação seja prorrogada por tanto tempo, isto é, por mais de dois anos. Ressaltou-se que, no caso da referida lei, embora não esteja clara a hipótese de ilimitadas prorrogações, cabe ao juiz interpretar tal possibilidade. Contudo, dada a natureza da norma que alude à restrição da liberdade, o que está ali previsto é uma exceção à regra. Se o texto legal parece estar indeterminado ou dúbio, cabe a esta Corte dar à norma interpretação estrita, face a sua natureza limitadora do direito à intimidade, de modo a atender ao verdadeiro espírito da lei. Com isso, concedeu-se a ordem de habeas corpus a fim de reputar ilícita a prova resultante de tantos dias de interceptações telefônicas e, conseqüentemente, declarar nulos os atos processuais pertinentes e retornar os autos ao juiz originário para determinações de direito". ${ }^{19}$
\end{abstract}

Na mesma trilha vem decidindo a Colenda $5^{\mathrm{a}}$. Turma do Superior

Tribunal de Justiça :

“(...) O afastamento da garantia inscrita no inciso XII do art. $5^{\circ}$ da CF pressupõe o cumprimento cumulativo, das exigências cogentes, imperativas, de ordem pública, de direito estrito, contida na Lei 9.296/96, notadamente a existência de indícios razoáveis da autoria ou participação em infração penal (art. $\left.2^{\circ}, \mathrm{I}\right)$, decisão judicial fundamentada, sob pena de nulidade, pelo prazo de quinze dias, renovável (art. $5^{\circ}$ ), que a infração não seja punida com detenção e, que não seja possível realizar a prova por outros meios disponíveis. O fato de a investigação ser sigilosa não exclui a necessidade de que a autoridade policial demonstre os indícios razoáveis da autoria ou participação do agente em infração penal, para que o Magistrado competente possa fazer seu juízo de convencimento a respeito, no sentido do atendimento ou não, da imperativa exigência apontada, para

${ }^{19}$ STJ. 6 $6^{\text {a }}$ Turma, HC no 76.686/PR, julg. 09.09.2008 
justificar a drástica medida invasiva do direito constitucional à incolumidade do sigilo, ut art. $5^{\circ}$, XII, da CF. É inadmissível a manutenção da prova resultante de interceptação oriunda de injustificada quebra do sigilo telefônico, por falta de qualificação do agente e indicação de indícios razoáveis da sua autoria ou participação em infração penal, da inadequada fundamentação das autorizações judiciais, conforme exige o parágrafo único do art. $2^{\circ}$ da Lei 9.296/96, por violar os princípios da razoabilidade, proporcionalidade e da dignidade da pessoa humana, ALÉM DO EXCESSIVO PERÍODO (660) DIAS, APROXIMADAMENTE, DA QUEBRA DO SIGILO. Ordem concedida para que sejam desentranhadas do Inquérito 2202.35.00.012047-8 todas as gravações interceptadas a partir e recebidas do telefone do paciente". ${ }^{20}$

\title{
Do voto do Relator, ainda se colhe :
}

\begin{abstract}
"Revela-se, pois, abusiva a manutenção da prova resultante da interceptação das comunicações telefônicas, no período respectivo, oriundas da injustificada quebra do sigilo da linha (61-9976.6449), do qual era usuário o Paciente, por falta da indicação de indícios razoáveis da sua autoria ou participação, da inadequada fundamentação, quanto a ele, das autorizações judiciais, de sua qualificação, conforme exige o parágrafo único, do art. $2^{\circ}$, quando possível, e tal o era pois dito que poderia ser encontrado no gabinete do deputado, da exagerada duração da medida, 660 dias, aproximados, o que viola os princípios da razoabilidade e da proporcionalidade, em seus alcances, como limitadores de exageros por parte, sobretudo, das autoridades, atentando, inclusive, contra o princípio magno e sensível da dignidade da pessoa humana, pois é deveras inconcebível que, a não ser em situações absolutamente excepcionais e exuberantemente justificadas, perdure, por tanto tempo, a execução, como se qualifica medida consistente na quebra do sigilo. Não foi outra, aliás, a razão que levou o legislador a cercar tal providência de várias cautelas, como se colhe do inteiro teor da Lei 9.296/96, que deve, por isso mesmo, ser aplicada com as imprescindíveis moderação e parcimônia, até mesmo para emprestar a necessária higidez e credibilidade, como fato de convencimento, às provas colhidas por tal meio".
\end{abstract}

\section{Diferente não está sendo o posicionamento dos Tribunais Regionais}

\section{Federais, merecendo destaque :}

“... por força de literal disposição da norma encastelada no art. 5 da Lei 9.296/96, não somente a decisão que defere a instalação da escuta telefônica, mas, igualmente, a que a prorroga, deverá ser sempre fundamentada, sob pena de nulidade. Assim, dispõe o indigitado dispositivo legal que a decisão será fundamentada, sob pena de nulidade, indicando também a forma de execução da diligência, que não poderá exceder o prazo de quinze dias, renovável por igual tempo uma vez comprovada a indispensabilidade do meio de prova. (...) Vale frisar, outrossim, que a matéria ora debatida se encontra na ordem do dia, sendo,

${ }^{20}$ STJ. $\quad 5^{a}$. Turma, HC n ${ }^{0}$ 88.825, Rel. Min. Arnaldo Esteves Lima, julg. 15.10.2009, Dje 
inclusive, objeto de debate em uma CPI, a chamada CPI do Grampo. Ademais, o projeto de lei (...) que limita em sessenta dias o prazo para a escuta, prorrogáveis por mais sessenta, até o máximo de trezentos e sessenta dias, já foi aprovado na Comissão de Constituição e Justiça do Senado, donde ser autorizado concluir, sem medo de errar, que a tendência mais moderna é realmente pela limitação temporal, evitando-se, a todo custo, o deferimento de quebras de sigilo por prazo indeterminado". ${ }^{21}$

A atual interpretação que vem sendo dada ao tema pela jurisprudência tem sido aplaudida pela doutrina, eis que é a mais compatível com outras normas da própria Constituição.

Em interpretação sistemática de texto constitucional existe um argumento a respeito do lapso temporal da violação do sigilo que nos parece irrespondível. O artigo 136, da Carta Magna, ao tratar do estado de defesa, prevê, em seu $\S 1^{\circ}$, inciso I, alínea “c”, como uma das restrições de direitos admitidas durante tal estado de exceção, exatamente a quebra do sigilo das comunicações telegráficas e telefônicas.

Entretanto, o $\S 2^{\circ}$, do mesmo artigo 136, limita o tempo do estado de defesa em no máximo 60 (sessenta) dias, ao estabelecer:

“O tempo de duração do estado de defesa não será superior a trinta dias, podendo ser prorrogado uma vez, por igual período, se persistirem as razões que justificaram sua decretação”.

Ora, se a própria Constituição da República limita a restrição ao direito de sigilo das comunicações telefônicas em 60 (sessenta) dias, quando diante da excepcionalíssima hipótese de estado de defesa, como se poderia admitir, em situação de normalidade, o afastamento do sigilo indefinidamente?

\footnotetext{
${ }^{21}$ TRF-5 ${ }^{\text {a }}$ Reg. $3^{\text {a }}$. Turma, HC no 2008.05.00.063846-9, Rel. Des. Fed. Vladimir Carvalho, julg. 25.09.2008, DJU 18.11.2008, IBCCrim nº 194, pág. 1231
} 
A esse propósito, registre-se, por oportuno, a lição do Magistrado GERALDO PRADO, que resolveu tecer algumas considerações críticas acerca de julgados que se posicionaram no sentido de que a prorrogação poderia ser deferida por períodos indefinidos. Diz ele :

\begin{abstract}
“Ora, aceitar como no acórdão a violação ao sigilo das comunicações telefônicas por mais de sessenta dias configura contra-senso em comparação com a mesma medida em defesa da Constituição da República, em caráter excepcional.

Supor que o mais grave estado de instabilidade social deve ser tratado com medidas mais brandas que as dirigidas ao controle da criminalidade comum, ainda que envolvida em crimes violentos, praticados por organizações criminosas ou contra a ordem econômica, não é razoável!

(...)

O resultado da aplicação da tese deste trabalho ao acórdão citado no início consiste em concluir que a solução encontrada pelo tribunal, admitindo sucessivas prorrogações de interceptações telefônicas, no lugar de definir o prazo máximo de trinta dias (quinze) dias, prorrogável uma vez por mais quinze, como única interpretação do artigo $5^{\circ}$ da Lei ${ }^{\circ}$ 9.296/96, conforme a Constituição, equipara a restrição (provisória) do direito à inviolabilidade das comunicações telefônicas à suspensão (temporária) do sigilo das mencionadas comunicações, tratando mais gravemente situação jurídica que por expressa previsão constitucional não é equiparável ao estado de defesa (artigo 136 da Constituição da República). Ferese o princípio da razoabilidade e se afasta da interpretação sistemática da Constituição, concedendo primazia à função de segurança pública em detrimento do papel assinalado ao juiz pela Carta de 1988, tal seja, o de garantidor dos direitos fundamentais". ${ }^{22}$
\end{abstract}

A mudança na orientação jurisprudencial e os argumentos utilizados na obra do Magistrado acima citado parecem irrespondíveis e, por esse motivo, não poderão deixar de ser aplicados, de modo a que a medida excepcional passe a ter limites quanto ao tempo de sua duração.

\title{
4.9 - Do delito cometido em razão de interceptações ilegais
}

Prescreve o art. 10 :

\footnotetext{
${ }^{22}$ PRADO, Geraldo. Limite às Interpretações Telefônicas e Jurisprudência do Superior Tribunal de Justiça, Lúmen Júris Editora
} 
"Constitui crime realizar interceptação de comuni-cações telefônicas, de informática ou telemática, ou quebrar segredo de Justiça, sem autorização judicial ou com objetivos não autorizados em lei”.

Embora excessos e abusos sejam constantemente praticados, a realidade é que a norma incriminadora pouco ou nada tem sido aplicada, muito embora a infringência da mesma seja conduta altamente condenável, uma vez que atinge um precioso direito do cidadão.

De qualquer maneira e modo a Lei n ${ }^{\circ}$ 9.296/96 não poderia deixar de prever figura penal que sujeitasse os seus infratores ao recebimento de sanção, sob pena de que a garantia constitucional se traduzisse em letra morta.

O dispositivo em exame também não foi poupado de críticas, mas, há de ser reconhecido que ele tem como destinatários aqueles que, sem autorização judicial, procedem a interceptações telefônicas, de informática ou telemática, como, também, que quebram o segredo de justiça com objetivos não autorizados em lei.

ADA PELLEGRINI GRINOVER sustenta que o dispositivo “colhe os servidores e agentes públicos inclusive o juiz que acaso autorize a interceptação para fins diversos da investigação criminal ou da instrução processual penal”. Prossegue a renomada autora :

"A redação do dispositivo deixa dúvidas quanto à caracterização do ilícito em casos que não se ligam propriamente aos "objetivos autorizados em lei”, como seria o do juiz que determinasse a interceptação para investigação de processo atinente a crime punido com pena de detenção". ${ }^{23}$

Ao que nos parece a figura penal em questão, notadamente no que se refere à interceptação telefônica, dificilmente poderá ser aplicada ao juiz,

${ }^{23}$ GRINOVER, Ada Pellegrini. Rev. For. 340, págs. 99/106 
pois, se ele intervém na mesma, estará proferindo decisão judicial autorizando a sua realização.

As precauções que o magistrado não pode deixar de observar são aquelas constantes das hipóteses proibitivas do art. $2^{\circ}$, quais sejam, atentar para a existência de indícios razoáveis de autoria ou participação; que a prova não possa ser produzida por outros meios; e que o fato investigado seja punido com pena de reclusão.

Precisamente para que essas proibições não venham a ser violadas é que o art. $5^{\circ}$ exige que a decisão seja devidamente fundamentada.

É certo que casos devem existir em que haja dificuldade para que se determine, com precisão, o tipo exato do crime e, por via de conseqüência, a pena a que pode estar sujeito o investigado, se de reclusão ou detenção. Nessa hipótese, caso a conclusão das investigações seja no sentido de que a ilicitude apenas pode gerar a aplicação de pena de detenção, as interceptações colhidas não devem ser utilizadas, mas, ao contrário, inutilizadas, na forma prevista no art. 9º da Lei de Regência.

Esse é o posicionamento da jurisprudência :

\begin{abstract}
“’”Prova - Interceptação telefônica - Hipótese de crimes apenados com detenção - Deferimento - Impossibilidade - Falta de amparo legal - Inteligência do art. $2^{\circ}$ da Lei 9.29696 e art. 5º XII, da Constituição da República - A Lei 9.296/96, que regulamenta a parte final do inc. XII do art. $5^{\circ}$ da Constituição Federal exclui de forma absoluta a possibilidade de interceptação de comunicações telefônicas em hipóteses de crimes apenados com detenção, como por exemplo a ameaça e a injúria, ressaltando-se que, se por um lado é justo estender a medida a esses crimes, em razão da relevante natureza jurídica do bem a tutelar e da maneira de execução, onde a autoria dificilmente pode ser descoberta de outra forma, por outro, poder-se-iam, ainda que involuntariamente, se devassar a intimidade e o sigilo de comunicações de pessoas inocentes; assim, esses motivos e falta de amparo legal implicam o não deferimento do pedido com tal fim”. ${ }^{24}$
\end{abstract}

\footnotetext{
${ }^{24}$ TACRIM/SP, 14 . Câm., Ap. 1.111.371/6, Rel. Renê Ricupero, RT 761/626 e RJTACrim 40/59
} 
No que se refere à segunda parte do dispositivo em exame, ou seja, a quebra do segredo de justiça, sem autorização judicial ou com objetivos não autorizados em lei, não precisa ser operador do direito para, a todo o instante, constatar-se a violação à norma, principalmente, através da mídia.

É indubitável que toda a tramitação das interceptações telefônicas devem ser processadas em segredo de justiça, eis que o art. $8^{\circ}$ é expresso :

“A interceptação de comunicação telefônica, de qualquer natureza, ocorrerá em autos apartados, apensados aos autos do inquérito policial ou do processo criminal, preservando-se o sigilo das diligências, gravações e transcrições respectivas".

É evidente que nessa fase o acesso ao material interceptado só pode ser de policiais, membros do Ministério Público, serventuários e juiz, pois, a franquia para o acusado e seu defensor somente se dá após terem sido os elementos de prova documentados em procedimento investigatório realizado por órgão com competência de policia judiciária, como estabelece a Súmula Vinculante n ${ }^{\circ}$ 14, editada pelo Excelso Pretório.

A divulgação de gravações e transcrições, quando veiculadas pela mídia sem autorização judicial e com objetivos não autorizados pela lei, deveria ser objeto de rigorosa apuração, de modo a que os seus responsáveis recebessem resposta penal, pois, além de ser ato delituoso, por vezes, atingem pessoas de bem, expondo-as à execração pública e, o que é pior, à condição de culpado, sem que tenha sido julgado, em evidente afronto ao princípio da presunção da inocência.

\subsection{0 - Pode o Juiz, "de ofício" não pode determinar interceptação}

Estabelece $o$ art. $3^{\circ}$ : 
“A interceptação das comunicações telefônicas poderá ser determinada pelo juiz, de ofício ou a requeri-mento :

I - da autoridade policial, na investigação criminal;

II - do representante do Ministério Público, na inves- tigação criminal e na instrução processual penal”.

Quanto à previsão de que possa a autoridade policial ou representante do Ministério Público requererem a interceptação, nada a questionar, bastando que haja a instauração de investigação criminal ou ação penal em curso e sejam observadas as formalidades legais que autorizam a decretação da medida excepcional.

Mas, no que se refere à determinação da interceptação "de ofício” pelo Juiz, a melhor doutrina considera tal norma inconstitucional, por vulnerar a mesma o modelo acusatório de processo.

De fato, a admitir-se que o Juiz “de ofício" pode determinar a medida, não pode deixar de ser reconhecido que ele transformou-se em órgão produtor de provas e, por conseguinte, impedido de julgar os resultados posteriores, porque alcançaria um conhecimento prévio sobre a culpabilidade ou inocência do investigado ou acusado.

Neste sentido é o posicionamento de LUIZ FLÁVIO GOMES :

“É inconstitucional a interceptação telefônica "de ofício", em consequiência, porque vulnera o modelo acusatório de processo, processo de parte, instituído pela Constituição de 1988, quando considera os ofícios da acusação e da defesa como funções essenciais ao exercício da jurisdição, atribuindo esta aos juízes, que têm competência para processar e julgar, mas não para investigar, principalmente no âmbito extra-processual”. ${ }^{25}$

\footnotetext{
${ }^{25}$ GOMES, Luiz Flávio. Ob. Cit.
} 
A principal característica do sistema acusatório repousa na iniciativa das partes, devendo o órgão julgador manter-se neutro, pois, do contrário, toda a atividade jurisdicional ficará prejudicada. Quando muito, a atividade probatória do Juiz deve ficar restrita à instrução criminal e, mesmo assim, em caráter supletivo à atuação das partes.

Pelos termos do art. 129, da Constituição Federal, cabe ao Ministério Público a função acusatória, pelo que compete a este requerer a medida cautelar, não devendo o órgão julgador imiscuir-se na função acusatória, sob pena de perder a sua imparcialidade.

Observe-se que as modificações produzidas pela Lei no 11.690/08 em vários dispositivos do Código de Processo Penal, determinam que as testemunhas sejam inquiridas pelas partes, podendo apenas o Juiz formular perguntas complementares sobre pontos não esclarecidos.

Relembre-se, também, que o Projeto de Lei do Senado Federal $n^{\circ}$ 156/09, que institui um novo Código de Processo Penal, prevê a figura do juiz de garantias, com a atribuição específica de tutelar os direitos fundamentais das pessoas investigadas, no curso do inquérito policial.

É sabido que, atualmente, na fase de investigação a autoridade policial para requerer qualquer medida que acarrete restrição a direitos fundamentais do investigado, dirige-se ao Juiz, sendo dele a competência para decretar a quebra de qualquer modalidade de sigilo. Dentro desse contexto não há como deixar de admitir-se que o Juiz acaba por participar da investigação.

A Juíza SIMONE SCHREIDER, em artigo publicado sob o título “O Juiz de Garantias no Projeto do Código de Processo Penal”, salienta : 
"Quando, finalmente, a investigação é encerrada com seu clímax, que é a chamada operação policial, na qual se expedem comumente mandados de busca e apreensão e de prisão cautelar, o juiz já está absoluta-mente familiarizado com os fatos. Ele participou ativamente da investigação policial e já formou um juízo sobre o que ocorreu, quem são as pessoas envolvidas etc. Nesse cenário, é evidente que a defesa entra em desvantagem, e sua fala já não merece a mesma atenção e credibilidade daquele juiz. Ademais, se foi ele próprio quem avaliou a pertinência e a legalidade das medidas probatórias realizadas na fase préprocessual, é bastante imprová-vel que ele desqualifique a prova que foi produzida e mude de idéia quanto ao resultado que foi colhido”. ${ }^{26}$

\section{E conclui a ilustre Magistrada :}

"Assim, a regra que se pretende introduzir de que o juiz que participou da investigação não seja o mesmo que vai julgar o processo, sem dúvida, é consentânea com o sistema acusatório, eleito pelo constituinte de 1988. O juiz competente para processar e julgar a ação penal, não tendo sido instado a tomar decisões pertinentes à fase investigatória, estará muito mais qualificado para realizar o julgamento justo e imparcial. A participação no inquérito contamina o juiz, tornando muito mais árdua a tarefa da defesa de se fazer ouvir no processo.

Sem dúvida que o novo Código de Processo Penal poderia apenas instituir uma regra de impedimento, em que o juiz que houvesse tomado qualquer decisão na fase investigatória estaria impedido de atuar na fase processual. Contudo, o Projeto vai além, prevendo um juiz especializado, um juiz que terá a atribuição exclusiva de tutelar os direitos das pessoas investigadas e a legalidade da atuação dos órgãos de persecução".

A propósito do tema posto em discussão pela ilustre Magistrada, é válido que se mencione que o Superior Tribunal de Justiça, por sua Sexta

Turma, julgando habeas corpus da relatoria do Ministro CELSO LIMONGI, decidiu :

"REALIZAÇÃO DE INTERROGATÓRIO POR JUIZ DURANTE A FASE INQUISITÓRIA, ANTES DO OFERECIMENTO DA DENÚNCIA. IMPEDIMENTO DO MAGISTRADO. NULIDADE DOS ATOS. CORREIÇÃO PARCIAL. DECISÃO DO SUPERIOR TRIBUNAL DE JUSTIÇA NO RHC N ${ }^{\circ}$ 23.945. PREVALÊNCIA.

1. Havendo decisão do Superior Tribunal de Justiça quanto ao impedimento do Juiz e à validade dos atos por ele praticados, é esse acórdão que deve prevalecer, e não o que foi proferido pelo Tribunal de origem em correição parcial.

2. Quando do julgamento do RHC $n^{\circ}$ 23.945/SP, foram declarados nulos, além dos atos decisórios, toda a instrução processual dirigida pelo Juiz, por ter o

\footnotetext{
${ }^{26}$ Boletim IBCCrim n ${ }^{\circ} 213$, agosto/2010
} 
magistrado realizado os interrogatórios na fase inquisitória, antes de haver ação penal. Foram, de igual modo, declarados nulos os atos de investigação praticados por ele na fase administrativa, os quais devem ser desconsiderados na propositura da nova ação penal. Ressalva do ponto de vista do Relator.

3. No caso, é esse entendimento que prepondera no que tange à ação penal em questão.

4. Ordem concedida para declarar impedido o Juiz e para declarar a nulidade de todo o processo - não apenas dos atos decisórios, assim como dos atos praticados pelo magistrado durante a fase das investigações preliminares -, determinando que os interrogatórios por ele realizados nesse período sejam desentranhados dos autos de forma que não influenciem a opinio delicti do órgão acusatório na propositura da nova denúncia.

5. Extensão da ordem concedida de ofício aos demais corréus". ${ }^{27}$

Assim, o sistema acusatório e a condição de imparcialidade do Juiz, que traduz a separação das funções processuais entre acusador, juiz e defesa afastam, por completo, a possibilidade de o magistrado determinar "de ofício” a interceptação das comunicações telefônicas, pelo que nenhum absurdo existe em considerar a norma em questão como inconstitucional. 


\section{Capítulo V - QUESTÕES CONTROVERTIDAS}

\section{1 - Comissão Parlamentar de Inquérito pode decretar Interceptação telefônica?}

No passado, raramente eram instituídas Comissões Parlamentares de Inquérito, mas, ultimamente, elas teem sido criadas com grande freqüência. Basta que um determinado tema assuma relevância na mídia para que o Congresso Nacional instaure Comissão Parlamentar de Inquérito.

Infelizmente, na maioria das vezes, o objetivo das Comissões Parlamentares de Inquérito tem sido desvirtuado, acabando por constituirse em oportunidade para projeções e exibições políticas do que propriamente para apuração de fatos que venham a oferecer elementos para a instauração de procedimentos judiciais.

O certo é que a Carta Magna, em seu art. 58, estabelece que o Congresso Nacional pode criar comissões temporárias, dentre as quais se inclui a Comissão Parlamentar de Inquérito, cujos poderes estão previstos no $\S 3^{\circ}$ :

\footnotetext{
“As comissões parlamentares de inquérito, que terão poderes de investigação próprios das autoridades judiciais, além de outros previstos nos regimentos das respectivas Casas, serão criadas pela Câmara dos Deputados e pelo Senado Federal, em conjunto ou separadamente, mediante requerimento de um terço de seus membros, para a apuração de fato determinado e por prazo certo, sendo suas conclusões, se for o caso, encaminhadas ao Ministério Público, para que promova a responsabilidade civil ou criminal dos infratores”.
}

Muito embora o texto constitucional afirme que as comissões "terão poderes de investigação próprios das autoridades judiciais”, elas não poderão decretar a interceptação das comunicações telefônicas, isto porque 
no entendimento do Supremo Tribunal Federal deve ser observada a

cláusula constitucional da reserva de jurisdição, que incide sobre determinadas matérias, tais como : decretação de prisão, deferimento de buscas e interceptações telefônicas.

A esse propósito, decidiu o Excelso Pretório, ao julgar mandado de segurança relatado pelo Ministro CELSO DE MELLO :

“- O sigilo bancário, o sigilo fiscal e o sigilo telefônico (sigilo este que incide sobre os dados/registros telefônicos e que não se identifica com a inviolabilidade das comunicações telefônicas) - ainda que representem projeções específicas do direito à intimidade, fundado no art. 50 $\mathrm{X}$, da Carta Política - não se revelam oponíveis, em nosso sistema jurídico, às Comissões Parlamentares de Inquérito, eis que $o$ ato que lhes decreta a quebra traduz natural derivação dos poderes de investigação que foram conferidos, pela própria Constituição da República, aos órgãos de investigação parlamentar.

As Comissões Parlamentares de Inquérito, no entanto, para decretarem, legitimamente, por autoridade própria, a quebra do sigilo bancário, do sigilo fiscal e/ou do sigilo telefônico, relativamente a pessoas por elas investigadas, devem demonstrar, a partir de meros indícios, a existência concreta de causa provável que legitime a medida excepcional (ruptura da esfera de intimidade de quem se acha sob investigação), justificando a necessidade de sua efetivação no procedimento de ampla investigação dos fatos determinados que deram causa à instauração do inquérito parlamentar, sem prejuízo de ulterior controle jurisdicional dos atos em referência (CF, art. $5^{\circ}$, XXXV).

- As deliberações de qualquer Comissão Parlamentar de Inquérito, à semelhança do que também ocorre com as decisões judiciais (RTJ 140/514), quando destituídas de motivação, mostram-se írritas e despojadas de eficácia jurídica, pois nenhuma medida restritiva de direitos pode ser adotada pelo Poder Público, sem que $\mathrm{o}$ ato que a decreta seja adequadamente fundamentado pela autoridade estatal.” 28

No julgado transcrito, destaca o eminente Ministro :

"Cabe traçar aqui, por necessário, uma distinção entre a interceptação ("escuta”) das comunicações telefônicas, inteiramente submetidas ao princípio constitucional da reserva de jurisdição (CF, art. $5^{\circ}$, XII), de um lado, e a quebra do sigilo dos dados (registros) telefônicos, de outro, cuja tutela deriva da cláusula de proteção à intimidade inscrita no Artigo 5º X, da Carta Política”.

\footnotetext{
${ }^{28}$ STF. MS n ${ }^{\circ}$ 23.452, Rel. Min. Celso de Mello
} 
Desse julgado, o seu ilustre Relator aproveitou magistério de LUIZ FLÁVIO GOMES, em que consta :

“As Comissões Parlamentares de Inquérito podem decretar a quebra do sigilo dos “dados telefônicos” ? Têm poderes para isso ? Esses "dados pessoais” estão protegidos pela Constituição Brasileira (art. 50, inciso XII) de modo absoluto ou relativo ? Poderiam, tais CPIs determinar a "escuta telefônica" prevista na Lei 9.296/96 ? Essa lei alcança inclusive os dados telefônicos ou tão-somente as comunicações telefônicas presentes, atuais ?

(...)

Desde logo, é preciso salientar, Uma coisa é a “comunicação telefônica” em si, outra, bem diferente, são os registros pertinentes às comunicações telefônicas, registros esses que são documentados e armazenados pela companhia telefônica, tais como : data da chamada telefônica, horário, número do telefone chamado, duração do uso, valor da chamada etc. Vêm estampados nas denominadas “contas telefônicas", que também integram o ampla espectro da "privacidade" da pessoa. A interceptação de uma comunicação telefônica versa sobre algo que está ocorrendo, atual; já a quebra do sigilo de dados telefônicos relaciona-se com chamadas telefônicas pretéritas, já realizadas.

A Constituição Federal distinguiu, no inciso XII do art. 50, os “dados” das “comunicações telefônicas” e, aparentemente, conferiu àqueles uma tutela absoluta (como se sabe, prima facie, tem-se a impressão de que a Carta Magna só permitiu a quebra do sigilo das comunicações telefônicas).

O ponto de partida para o verdadeiro entendimento do assunto reside em reconhecer a "relatividade" dos direitos fundamentais (muitos chamados de "liberdades públicas" no antigo direito francês). O princípio do sigilo absoluto não se coaduna com a realidade e a necessidade sociais. Os dados pessoais, em conclusão, seja no momento de uma comunicação (telefônica ou por outra forma), sejam os armazenados (estanques), não gozam de sigilo absoluto.

(...)

E não é o caso (...) de se aplicar a Lei 9.296/96 aos registros (“dados”) telefônicos, pois ela só disciplina a interceptação (ou escuta) telefônica.

Em suma : os dados telefônicos (registros pertinentes a chamadas pretéritas) não contam com sigilo absoluto. Por ordem judicial, em regra, pode ser quebrado esse sigilo, mas sempre que houver autorização legal, distinta da Lei 9.296/96.

Considerando que, por força do art. 58, $\S 3^{\circ}$, da Constituição Federal, as Comissões Parlamentares de Inquérito possuem poderes de investigação próprias das autoridades judiciais e tendo em vista, ainda, que a Lei $\mathrm{n}^{\circ} 1.579 / 52$, art. $2^{\circ}$, possibilita-lhes a requisição de informações e documentos de órgãos públicos ou autárquicos (incluindo-se as concessionárias de serviço público), cabe concluir : a quebra do sigilo dos dados telefônicos pode ser determinada por CPI. Essa iniciativa conta com amparo legal.

O que não podem as CPIs é determinar escuta ou interceptação telefônica, que só podem ocorrer "para fins criminais", dentro de uma investigação criminal ou dentro de uma instrução processual penal. E a CPI é criada para a apuração de fatos administrativos. Não é uma investigação criminal. Não se destina a apurar crimes nem a puni-los, pois essas atividades são da competência dos Poderes Executivos e Judiciário. Se no curso de uma investigação administrativa vier a deparar com fatos criminosos, deles dará ciência ao Ministério Público (H.C. 71.039-RJ, STF, Rel. Paulo Brossard).

A Comissão Parlamentar de Inquérito, em síntese, deve contar com meios suficientes para o bom desempenho das suas atribuições. Seus poderes são amplos, embora não ilimitados. A quebra do sigilo dos dados telefônicos não 
constitui excesso de poder. Apenas alguns atos é que são da competência exclusiva do Poder Judiciário : escuta telefônica e decretação de prisão, por exemplo". ${ }^{29}$

Assim, na conformidade do posicionamento jurisprudencial da Suprema Corte e da doutrina predominante, constata-se que as Comissões Parlamentares de Inquérito podem decidir pela quebra dos dados/registros telefônicos, mas, todavia, estão impedidas de quebrar as interceptações telefônicas mediante escuta, face ao princípio constitucional da reserva de jurisdição.

\section{2 - As conversações dos advogados com os seus clientes não podem ser interceptadas}

A Constituição Federal, em seu art. 133, prevê que o advogado é indispensável à administração da justiça, possuindo inviolabilidade por seus atos e manifestações no exercício da profissão, nos limites da lei.

Por sua vez, a Lei $n^{\circ}$ 8.906, de 4 de julho de 1994, no art. $7^{\circ}$, inciso II, com a nova redação que lhe foi dada pela Lei $n^{0} 11.767 / 2008$, preceitua ser direito do advogado "a inviolabilidade de seu escritório ou local de trabalho, bem como de seus instrumentos de trabalho, de sua correspondência escrita, eletrônica, telefônica e telemática, desde que relativas ao exercício da advocacia".

Entretanto, apesar da garantia constitucional e da expressa previsão no Estatuto da Advocacia e da $\mathrm{OAB}$, os anais forenses registram várias violações ao exercício da advocacia, havendo casos, inclusive, de buscas e apreensões ilegais em escritórios, de interceptação de conversações entre

\footnotetext{
${ }^{29}$ GOMES, Luiz Flávio. A CPI e a Quebra do Sigilo Telefônico, Cadernos "Direito e Justiça", Correio Braziliense de 28.04.1997
} 
advogado e seu cliente e, como noticiado recentemente, de gravações de áudio e vídeo em parlatórios, por ocasião de entrevistas reservadas em presídio, o que afronta o inciso III, do art. $7^{\circ}$, da Lei nº 8.906/94.

A violação das prerrogativas dos advogados não só constitui ilicitude quanto ao profissional, como, também, atinge o direito do cidadão, constituindo-se, ainda, em prática inconstitucional, absolutamente incompatível com o Estado Democrático de Direito.

Atente-se que a garantia assegurada ao exercício da advocacia no Brasil está em absoluta consonância com a legislação de outros países, como é o caso italiano, eis que o Código de Processo Penal, em seu art. 271, $n^{0} 2$, proíbe a interceptação das comunicações telefônicas das pessoas que devem guardar segredo profissional, incluindo-se, aí, o advogado.

Do mesmo modo é a legislação portuguesa, pois, o art. $187, \mathrm{n}^{\circ} 3$, do Código de Processo Penal, de forma expressa, estabelece que é proibida a interceptação e a gravação de conversações ou comunicações entre o argüido e seu defensor, salvo se o juiz tiver fundadas razões para crer que elas constituem objeto ou elemento do crime.

No nosso direito, inobstante a Lei $n^{\circ}$ 9.296/96 não contenha dispositivo tratando do tema, o certo é que a doutrina é unânime no sentido de que a interceptação da conversa mantida entre advogado e acusado é medida que redunda em violação do segredo profissional e, por conseguinte, quando decretada, constitui-se em decisão e prova ilegal.

O Ministro VICENTE CERNICCHIARO, em artigo de sua autoria, afirma :

"Evidente, a interceptação não pode colher a conversa do indiciado, ou do réu com seu advogado. Vou além, De qualquer pessoa que procure o profissional a 
fim de aconselhar-se porque praticara uma infração penal. Será contraditório o Estado obrigar o advogado a guardar segredo profissional e imiscuir-se na conversa e dela valer-se para punir o crime. O Direito não admite contradição lógica !” ${ }^{30}$

Entretanto, há que se destacar que quando a profissão for utilizada para o cometimento de delitos pelo advogado e ele estiver na condição de investigado, ele passa a ostentar a condição de mero cidadão e, assim, pode ter a sua conversa telefônica normalmente interpretada, desde que presentes os requisitos da lei.

\section{3 - Denúncia anônima não autoriza o deferimento de interceptações telefônicas}

A Constituição Federal, em seu art. 50, inciso IV, preceitua que "é livre a manifestação do pensamento, sendo vedado o anonimato”. Outras leis, dentre as quais pode ser mencionada a Lei $\mathrm{n}^{\circ}$ 8.112/90, também exigem a identificação do denunciante, tanto que o seu art. 144 estabelece : “As denúncias sobre irregularidades serão objeto de apuração, desde que contenham a identificação e o endereço do denunciante e sejam formuladas por escrito, confirmada a autenticidade”.

A Resolução no 290/04, normatizando eventual chegada de denúncia anônima à Suprema Corte, preceitua em seu art. $4^{\circ}$ :

\footnotetext{
“Não serão admitidas pela Ouvidoria :

II - reclamações, críticas ou denúncias anônimas;

$\S 1^{\circ}$ - Nas hipóteses previstas nos incisos I e II, o pedido terá seu processamento rejeitado liminarmente e será imediatamente devolvido ou comunicada a decisão ao remetente".
}

\footnotetext{
${ }^{30}$ Boletim IBCCrim n ${ }^{\circ} 47$
} 
O Supremo Tribunal Federal, em decisão proferida em habeas corpus da relatoria do Min. Marco Aurélio, trancou noticia crime instaurada perante o STJ contra juiz estadual e desembargadores do Tribunal de Justiça do Estado de Tocantins com base unicamente em denúncia anônima, fixando em sua ementa :

“ANONIMATO - NOTICIA DE PRÁTICA CRIMINOSA - PERSECUÇÃO CRIMINAL - IMPROPRIEDADE. Não serve à persecução criminal notícia da prática criminosa sem identificação da autoria, consideradas a vedação constitucional do anonimato e a necessidade de haver parâmetros próprios à responsabilidade, nos campos cível e penal, de quem a implemente”. ${ }^{31}$

Em seu longo voto, destaca o eminente Ministro :

“...

Acrescento que, se de um lado há que se ouvir o cidadão, de se preservar a manifestação do pensamento, de outro, a própria Constituição Federal veda o anonimato - inciso IV do artigo $5^{\circ}$. Sob o ângulo da inviolabilidade da vida privada, é ainda a Carta da República que assegura o direito à indenização pelo dano material ou moral decorrente da inobservância da vedação. É justamente esse contexto que bem diz com a vida em um Estado Democrático de Direito, com a respeitabilidade própria ao convívio das pessoas em cultura satisfatória que direciona à impossibilidade de se agasalhar o denuncismo irresponsável, maculando-se, sem seriedade maior, a vida das pessoas. Sim, tudo deve merecer enfoque visando à preservação da dignidade da pessoa humana que, conforme já assinalado, é fundamento da República Federativa do Brasil. A se agasalhar a óptica da denúncia anônima, mediante carta apócrifa, ter-se-á a porta à vindita, à atuação voltada tão somente a prejudicar desafetos, alguém que tenha contrariado interesses.

A envergadura do tema contrasta, a mais não poder, com a vida democrática, com a segurança jurídica que deve se fazer presente no dia-a-dia dos cidadãos. A esta altura, acolher a referida prática é dar asa à repetição desse procedimento, passando-se a viver época de terror, em que a honra das pessoas ficará ao sabor de paixões condenáveis, não tendo elas meio de incriminar aquele que venha a implementar verdadeira calúnia. O interesse público não está nesse modo de se chegar à responsabilidade de servidores e agentes públicos, mas, tanto quanto possível, na preservação da imagem daqueles que atuam no serviço público, especialmente como agentes públicos e políticos.

${ }^{31}$ STF. HC n ${ }^{\text {o }} 84.827,1^{\text {a }}$. Turma, DJ 23.11.2007 
Coerente com tais premissas é que esta Casa aprovou a Resolução n ${ }^{\circ}$ 290, de 5 de maio de 2004, criando a Ouvidoria do Supremo Tribunal Federal, com o objetivo de contribuir para elevar continuamente os padrões de transparência, presteza e segurança das atividades aqui desenvolvidas. Como que a confirmar que esta corte não compactua com o procedimento covarde de quem se escusa da responsabilidade que deve nortear o exercício da cidadania, já no inciso II do artigo $4^{\circ}$ daquela Resolução está registrado que não serão admitidas pela Ouvidoria reclamações, críticas ou denúncias anônimas, esclarecendo-se, no $\S 1^{\circ}$, que, nesses casos, "o pedido terá seu processamento rejeitado liminarmente e será imediatamente devolvido ou comunicada a decisão ao remetente”.

Mais do que isso, julgando o Mandado de Segurança $n^{\circ}$ 24.405-4/DF, sob a relatoria do ministro Carlos Velloso, o Plenário glosou o artigo 55 da Lei ${ }^{\circ}$ 8.443/92 quanto à manutenção do sigilo da autoria de denúncia ao Tribunal de Contas da União.

Claro está, então, que, sob pretextos os mais casuísticos, não se há de acobertar aquele que, valendo-se do anonimato, ofende quem quer que seja, agravando-se mais ainda o pusilânime ato, a abjeta acusação se dirigida a um administrador da coisa pública, cujo prejuízo será maior, ante as peculiaridades do cargo que ocupa, que o expõe a elevada evidência social. Seria usar de dois pesos e duas medidas permitir o gravame e impossibilitar o eventual reparo, com afronta aos princípios consagrados no artigo $5^{\circ}$ da Constituição Federal, mormente ao inciso $\mathrm{X}$ - que assegura a inviolabilidade do direito à imagem - e ao inciso V concernente ao direito de resposta, proporcional ao agravo, com ambas as normas a alicerçar a indenização por dano material e moral.

Portanto, de forma alguma, convém viabilizar o ensejo de práticas das mais odiosas - o denuncismo inescrupuloso e doidivanas que decorrerá necessariamente do fato de o denunciante saber-se protegido pelo sigilo nas acusações que faz sem querer responder pelas conseqüências quando do controle judicial do ato, enfim, quando da apuração e consagração da verdade dos fatos por si imputados a outrem, muitas vezes por puro ressentimento diante da proeminência do ofendido, inconformismo que o próprio fracasso, ou ainda por outros sentimentos menos nobres e igualmente inconfessáveis”.

Diante das normas mencionadas e de outras existentes a respeito do tema, bem assim do posicionamento jurisprudencial da Suprema Corte, o que se questiona é : com lastro, apenas, em denúncia anônima pode ser requerida e decretada a quebra de interceptações telefônicas ?

Sendo a interceptação telefônica uma medida excepcional, que atinge de forma violenta a privacidade do cidadão, pode parecer um exagero trazer o tema à discussão. Mas, desde o instante em que os tribunais já foram chamados a pronunciarem-se a respeito, é porque interceptações foram decretadas em função de denúncias anônimas. 
O Egrégio SUPERIOR TRIBUNAL DE JUSTIÇA, em vários julgados, tem entendido :

"HABEAS CORPUS. SONEGAÇÃO FISCAL. LAVAGEM DE DINHEIRO E
CORRUPÇÃO. DENÚNCIA ANÔNIMA. INSTAURAÇÃO DE INQUÉRITO
POLICIAL. POSSIBILIDADE. INTERCEPTAÇÂO TELEFÔNICA.
IMPOSSIBI-LIDADE. PROVA ILÍCITA. TEORIA DOS FRUTOS DA
ARVORE ENVENENADA. NULIDADE DE PROVAS VICIADAS, SEM
PREJUÍZO DA TRAMITAÇÃO DO PROCEDIMENTO INVESTIGATIVO.
ORDEM PARCIAMENTE CONCEDIDA; 1. Hipótese em que a instauração do inquérito policial e a quebra do sigilo telefônico foram motivadas exclusivamente por denúncia anônima.

2. "Ainda que com reservas, a denúncia anônima é admitida em nosso ordenamento jurídico, sendo considerada apta a deflagrar procedimentos de averiguação, como o inquérito policial, conforme contenham ou não elementos informativos idôneos suficientes, e desde que observadas as devidas cautelas no que diz respeito à identidade do investigado. Precedentes do STJ (HC 44.649/SP, Rel. Min. LAURITA VAZ, Quinta Turma, DJ 8/10/07).

3. Dispõe o art. $2^{\circ}$, inciso I, da Lei 9.296/96, que "não será admitida a interceptação de comunicações telefônicas quando (...) não houver indícios razoáveis da autoria ou participação em infração penal”. A delação anônima não constitui elemento de prova sobre a autoria delitiva, ainda que indiciária, mas mera noticia dirigida por pessoa sem nenhum compromisso com a veracidade do conteúdo de suas informações, haja vista que a falta de identificação inviabiliza, inclusive, a sua responsabilização pela prática de denunciação caluniosa (art. 339 do Código Penal).

4. A prova ilícita obtida por meio de interceptação telefônica ilegal igualmente corrompe as demais provas dela decorrentes, sendo inadmissíveis para embasar eventual juízo de condenação (art. 5º inciso LVI, da Constituição Federal). Aplicação da "teoria dos frutos da árvore envenenada".

$(\ldots)^{32}$

Vale destacar que em seu voto o Ministro Relator faz referência a acórdão proferido pelo Tribunal Regional Federal da $4^{\mathrm{a}}$. Região no $\mathrm{HC} \mathrm{n}^{\mathrm{o}}$ 2005.04.01.033419-0, do qual consta :

“(...)

2. Denúncia anônima não é prova, nem mesmo indiciária; é mera informação. Poderia como informação até justificar iniciais providências investigatórias pela polícia ou pelo Ministério Público, mas jamais fundamentar restrições a direitos individuais (como prisão, busca domiciliar, quebra de sigilos, cautelares penais

\footnotetext{
${ }^{32}$ STJ. HC n ${ }^{\circ}$ 64.096, Rel. Min. Arnaldo Esteves Lima, julg. em 27.05.2008, DJU de 04.08.2008
} 
típicas e indiciamento). Precedente claro do Supremo Tribunal Federal Inquérito $\mathrm{n}^{\circ}$ 1.975/PR.

3. É ilícita a interceptação telefônica fundada exclusivamente em denúncia anônima, contaminando com tal ilicitude as provas conseqüentes.

$(\ldots)$ "

Frise-se, ainda, que do acórdão transcrito consta voto vencido do Ministro NAPOLEÃO NUNES MAIA, que concedia a ordem em maior extensão, entendendo "que tudo que foi produzido não tem prestabilidade", afirmando :

\begin{abstract}
"Por isso, meu voto é no sentido da concessão da ordem de habeas corpus, trancando esse inquérito, sem prejuízo de que a autoridade policial instaure outro, dentro da normalidade jurídica e legal, podendo aproveitar ou não o que foi apurado, mas terá que fazer outro inquérito, inclusive não pode se iniciar com a quebra de sigilo, e sim com as providências ordinárias, comuns, triviais no sentido de captar os indícios de coletar as provas. E não começar quebrando sigilo telefônico da pessoa, ainda que não fosse oriundo de uma denúncia anônima, mas de uma denúncia subscrita e com firma reconhecida; ainda assim, não poderia começar quebrando o sigilo. Teria de chamar a pessoa apontada, indagar os fatos, pedir esclarecimentos, livros fiscais, documentação, enfim, fazer como a Receita Federal faz para apurar a prática de um ilícito, e não começar quebrando a coisa preciosa que é o resguardo da intimidade”.
\end{abstract}

Existem outras decisões no mesmo sentido, merecendo destaque a seguinte :

"Denúncia anônima não é prova, nem mesmo indiciária; é mera informação. Pode, como informação, até justificar providências investigatórias pela policia ou Ministério Público, mas jamais interferir restringindo direito individual. A quebra de direitos individuais, que é possível na forma da lei e dentro dos limites do razoável e necessário, exige relevância probatória mínima. Nas situações processuais em que é atingido pessoalmente o processado/investigado, é imprescindível prévio e sério conjunto indiciário de provas. Admito, porém, como lícito ao Ministério Público e à policia investigarem a partir de denúncias anônimas. Podem acompanhar os envolvidos, buscar testemunhas, reunir elementos probatórios e pleitear justificadamente, então - e apenas então medidas restritivas individuais. Para o deferimento dessas medidas de urgência invasivas não será necessário juízo de certeza, mas ao menos indícios probatórios sérios serão sempre exigíveis previamente”. ${ }^{33}$

\footnotetext{
${ }^{33}$ TRF-4 ${ }^{a}$.Reg. HC no 2009.04.00.033380-6, Rel. Des. Fed. Néfi Cordeiro, julg. em 3.11.2007, 
Mencione-se, ainda, decisão monocrática proferida pelo Presidente do Superior Tribunal de Justiça, Ministro CESAR ASFOR ROCHA :

\begin{abstract}
“...
Cumpre observar que o sistema jurídico do País e o seu ordenamento positivo não aceitam que o escrito anônimo possa, em linha de princípio e por si, isoladamente considerado, justificar a imediata instauração da persecutio criminis, porquanto a Constituição proscreve o anonimato (art. 5º IV), daí resultando o inegável desvalor jurídico de qualquer ato oficial de qualquer agente estatal que repouse o seu fundamento sobre comunicação anônima, como o reconheceu o Pleno do STF no julgamento do INQ 1957, Rel. Min. Cezar Peluzo (DJU de 11.11.2005), ainda que se admita que possa servir para instauração de averiguações preliminares, na forma do art. $5^{\circ}, \S 3^{\circ}$, do CPP, ao fim das quais se confirmará - ou não - a notícia dada por pessoa de identidade ignorada ou mediante escrito apócrifo...” ${ }^{34}$
\end{abstract}

Pelos julgados transcritos, conclui-se que a jurisprudência até admite que denúncia anônima possa justificar providências investigatórias, mas, jamais, em razão da mesma, ser deflagrada medida de interceptação telefônica que se preste à apuração da procedência ou improcedência da denúncia.

Não se perca de vista que aquele que imputa a alguém crime de que o sabe inocente, fica sujeito aos rigores da lei penal, mais precisamente à sanção prevista no art. 339, do Código Penal, cuja pena é aumentada quando o agente utiliza-se do anonimato ou de nome suposto. Ora, quem se vale desse modo de atuar, sem dúvida, não está querendo sujeitar-se a essa pena, preferindo esconder-se por trás da obscuridade.

\title{
5.4 - Podem as interceptações serem utilizadas - Para outros fins probatórios
}

Segundo FERNANDO CAPEZ, quando uma prova é colhida num determinado processo e a ele destinada, é depois transportada, por traslado,

\footnotetext{
${ }^{34}$ STJ. HC no 159.159, decisão proferida em 14.01.2010
} 
certidão ou qualquer outro meio autenticatório, para produzir efeito como prova em outro processo, estamos diante da chamada “prova emprestada”.

A validade da prova emprestada foi objeto de controvérsias doutrinárias e jurisprudenciais, mas, atualmente, predomina o entendimento de que a mesma é válida desde que provenha de processo em que as partes sejam as mesmas e trasladada para feito em que as partes continuem sendo as mesmas. Do contrário, sendo ela levada para outro processo, em que as partes são pessoas diversas, essa prova é inválida, uma vez que estaria violado o princípio do contraditório.

Nesse sentido é a jurisprudência do Superior Tribunal de Justiça :

"PENAL E PROCESSUAL. HABEAS CORPUS. ROUBO MAJORADO. CONDENAÇÃO FUNDA-MENTADA APENAS EM ELEMENTOS INFORMATIVOS DO INQUÉRITO E EM PROVA EMPRESTADA. IMPOSSIBILIDADE.

I - "ofende a garantia constitucional do contraditório fundar-se a condenação exclusivamente em elementos informativos do inquérito policial não ratificados em juízo" (Informativo-STF n ${ }^{\circ} 366$ ).

II - Não obstante o valor precário da prova empresta-da, ela é admissível no processo penal, desde que não constitua o único elemento de convicção a respaldar o convencimento do julgador (HC 67.707/RS, 1a ${ }^{\mathrm{a}}$. Turma, Rel. Min. Celso de Mello, DJU de 14/08/1992). Ademais, configura-se evidente violação às garantias constitucionais a condenação baseada em prova emprestada não submetida ao contraditório (HC 66.873/SP, $5^{\text {a }}$. Turma, Rel. Min. Gilson Dipp, DJ de 29/6/07 e REsp 499.177/RS, ta. Turma, Rel. Min. Paulo Gallotti, DJ de 02/4/07, como na hipótese de depoimento colhido, ainda que judicialmente, em processo estranho ao do réu (HC 47.813/RJ, 5a. Turma Rel. Min. Arnaldo Esteves Lima, DJ 10/09/2007.

III - In casu, o e. Tribunal de origem fundamentou sua convicção somente em depoimento policial, colhido na fase do inquérito policial, e em depoimento de adolescente supostamente envolvido nos fatos, colhido na Vara da Infância e da Juventude, deixando de indicar qualquer prova produzida durante a instrução criminal e, tampouco, de mencionar que aludidos elementos foram corroborados com as demais provas do processo.

Ordem concedida”. 35

\footnotetext{
${ }^{35}$ STJ. HC n ${ }^{\circ}$ 141.249/SP, 5a . Turma, Rel. Min. Felix Fischer, Dje 03.05.2010
} 
Vê-se, pois, que a prova emprestada pode ser usada em processo diverso daquele que motivou a sua produção, desde que tenha passado pelo crivo do contraditório da parte para a qual vai ser trasladada.

Entretanto, o art. $1^{\circ}$, da Lei $\mathrm{n}^{\mathrm{o}}$ 9.296/96, somente admite “a interceptação de comunicações telefônicas, de qualquer natureza, para prova em INVESTIGAÇÃO CRIMINAL e em INSTRUÇÃO PROCESSUAL PENAL”.

Então suponha-se que alguém tenha tido interceptadas suas conversações telefônicas em razão de investigação criminal que estava em andamento. Concluída a investigação um juiz cível ou uma autoridade administrativa requerem o fornecimento das degravações para serem utilizadas como prova compartilhada. Isso é possível ?

A matéria, em termos doutrinários, não é pacífica, pois, LUIZ FLÁVIO GOMES e RAÚL CERVINI sustentam :

\begin{abstract}
“O legislador constitucional ao delimitar a finalidade da interceptação telefônica (criminal) já estava ponderando valores, sopesando interesses. Nisso reside também o princípio da proporcionalidade. Segundo a imagem do legislador, justifica-se sacrificar o direito à intimidade para uma investigação ou processo criminal, não civil... Essa escolha, fundada na proporcionalidade, não pode ser desviada na praxe forense. Em conclusão, a prova colhida por interceptação telefônica no âmbito penal não pode ser “emprestada” (ou utilizada) para qualquer outro processo vinculado a outros ramos do direito... Ao permitir a interceptação, como quebra que é do sigilo das comunicações, somente para "fins criminais”, já fazia uso da ponderação e da proporcionalidade, que agora não pode ser ampliada na prática”. ${ }^{36}$
\end{abstract}

Inobstante, há entendimento de outros autores aceitando a possibilidade da admissão da prova emprestada, os quais sustentam que o valor protegido - intimidade - já teria sido violado e, por conseguinte, não havia mais qualquer proteção que pudesse ser reclamada.

\footnotetext{
${ }^{36}$ Ob. Cit.
} 
A orientação jurisprudencial da Suprema Corte tem admitido o compartilha-mento dos elementos colhidos mediante interceptação, como faz, dentre outros, o seguinte julgado :

"PROVA EMPRESTADA. Penal. Interceptação telefônica. Escuta ambiental. Autorização judicial e produção para fim de investigação criminal. Suspeita e delitos cometidos por autoridades e agentes públicos. Dados obtidos em inquérito policial. Uso em procedimento administrativo disciplinar, contra outros servidores, cujos eventuais ilícitos administrativos teriam despontado à colheita dessa prova. Admissibilidade. Resposta afirmativa a questão de ordem. Inteligência do art. 50 $5^{\circ}$ Inc. XII, da CF, e do art. $1^{\circ}$ da Lei federal $n^{\circ}$ 9.296/96. Precedente. Voto vencido. Dados obtidos em interceptação de comunicações telefônicas e em escutas ambientais, judicialmente autorizadas para produção de prova em investigação criminal ou em instrução processual penal, podem ser usadas em procedimento administrativo disciplinar, contra a mesma ou as mesmas pessoas em relação às quais foram colhidos, ou contra outros servidores cujos supostos ilícitos teriam despontado à colheita dessa prova”. ${ }^{37}$

Sendo o Excelso Pretório o guardião da Constituição e o intérprete maior das leis, não se tem como deixar de admitir que enquanto essa orientação vigorar, é possível o compartilhamento da prova advinda de interceptações telefônicas.

${ }^{37}$ STF. Questão de Ordem no Inquérito no 2.424, Rel. Min. Cezar Peluso, DJ 24.08.2007 


\section{Capítulo VI - A INTERVENÇÃO DE CORTES INTERNACIONAIS QUANTO AOS EXCESSOS PRATICADOS}

Como visto no sucinto exame que se fez acerca do tratamento dado por outras legislações quanto ao direito à privacidade, todas primam em têlo como regra, apenas admitindo-o em situações excepcionais.

Muito embora tais legislações contenham normas protetivas ao cidadão, o fato é que as mesmas teem sido violadas, o que tem gerado a intervenção de cortes internacionais.

A doutrina registra vários casos em que a Corte Européia de Direitos do Homem foi acionada porque determinados países atentaram contra sua própria legislação, submetendo indivíduos a interceptações telefônicas que se constituíram em verdadeiros abusos e, em razão disso, acabaram por ser condenados.

Dentre os vários casos relatados, um chama a atenção, por envolver o ex-primeiro ministro da Itália, Bettino Graxi, que teria sido vítima de interceptação ilegal e também de ilegal divulgação do seu conteúdo por parte da imprensa.

Pois bem. Esse falecido político, apesar de ter sustentado a ocorrência de cerceamento ao seu direito de defesa, acabou sendo condenado à pena de 8 anos de reclusão que, em grau de recurso, foi reduzida para 4 anos.

Em 2003, foi apresentada reclamação ao Tribunal Europeu, que a julgou procedente, por entender que o art. $8^{\circ}$, da Convenção Européia havia sido infringido em dois pontos : primeiro, pela divulgação pela imprensa do 
conteúdo da interceptação; em segundo, porque foi utilizada uma transcrição de uma interceptação pelo órgão acusador, à qual a defesa não teve acesso prévio. Em razão desse julgamento, a Itália foi condenada ao pagamento de expressiva indenização aos herdeiros do reclamante.

Saliente-se que o Estado brasileiro, em razão de excessos cometidos por agentes públicos quanto à aplicação da Lei nº 9.296/96, já foi levado à jurisdição da Corte Interamericana de Direitos Humanos, no caso ESCHER e Outros, tendo sido condenado ao pagamento de indenização a várias pessoas e outras sanções, por terem as mesmas interceptadas suas conversações telefônicas sem a observância das formalidades legais.

“O GLOBO”, em sua edição de 23.07.2010, publicou na íntegra a sentença proferida, merecendo destaque alguns de seus trechos :

“131. Quanto à interceptação telefônica, considerando que pode representar uma séria interferência na vida privada, tal medida deve estar fundamentada em lei, que deve ser precisa e indicar regras claras e detalhadas sobre a matéria, tais como as circunstâncias nas quais essa medida pode ser adotada; as pessoas autorizadas a solicitá-la, ordená-la e executá-la; o procedimento a seguir, entre outros elementos”.

No caso que ensejou a sentença, reconheceu a Corte que houve descumprimento às normas dos artigos $1^{\circ}$ e $8^{\circ}$, da Lei $n^{0} 9.296 / 96$, isto porque :

“133. De acordo com o artigo $1^{\circ}$ da Lei $\mathrm{N}^{\circ}$ 9.296/96, a interceptação telefônica deve ter o propósito de investigar criminalmente ou de instruir um processo penal. No presente caso, apesar de indicar a necessidade de investigar supostas práticas delituosas, quais sejam, o homicídio de Eduardo Aghinoni e o desvio de recursos públicos, a solicitação do major Neves não foi apresentada no marco de um procedimento investigativo que tivesse por objeto a verificação dos fatos. O pedido de interceptação sequer mencionou os autos da investigação do homicídio que se encontrava a cargo da policia civil de Querência do Norte, cujo delegado de policia não teria sido notificado a respeito. Outrossim, tampouco consta que na época dos fatos existisse uma investigação pelo suposto desvio de recursos públicos por parte dos dirigentes da COANA e da ADECON. Quanto ao pedido do sargento Silva, este não apontou o propósito das interceptações pretendidas nem sua vinculação com uma investigação ou processo penal. Desse modo, em 
detrimento do artigo $8^{\circ}$ da Lei $\mathrm{N}^{\circ}$ 9.296/96, o Pedido de Censura foi uma diligência isolada e não tramitou em autos anexos a um procedimento de investigação ou processo criminal iniciados anteriormente. Portanto, ambas as solicitações descumpriram como disposto nos artigos supracitados”.

Reconheceu também a Corte que foi afrontado o art. $3^{\circ}$, da Lei de Regência, tanto que é afirmado :

"134. Os pedidos de interceptação, bem como as decisões que os concederam, não expuseram quais eram os indícios razoáveis de autoria ou de participação dos membros da COANA e da ADECON nas infrações penais supostamente investigadas; os meios que seriam empregados para realizar a interceptação solicitada; nem, de forma clara, os fatos objeto da investigação. Tampouco demonstraram que o meio empregado era o único viável para obter tal prova. Em conseqüência, não foram observados os artigos $2^{\circ}$ e $4^{\circ}$ da Lei $N^{\circ}$ 9.296/96”.

Um outro aspecto que levou a Corte à prolação da sentença em exame foi a precariedade da fundamentação das decisões e, por conseguinte, a violação ao art. 5º da Lei nº 9.296/96 :

\begin{abstract}
“139. Em ocasiões anteriores, ao analisar as garantias judiciais, o Tribunal ressaltou que as decisões adotadas pelos órgãos internos que possam afetar direitos humanos, devem estar devidamente motivadas e fundamentadas, caso contrário, seriam decisões arbitrárias. As decisões devem expor, através de uma argumentação racional, os motivos nos quais se fundamentam, considerando as alegações e o acervo probatório aportado aos autos. O dever de motivar não exige uma resposta detalhada a cada argumento constante nas petições, podendo variar de acordo com a natureza de cada decisão. Cabe analisar em cada caso se essa garantia foi observada. Nos procedimentos cuja natureza jurídica exija que a decisão seja emitida sem a oitiva da outra parte, a motivação e a fundamentação devem demonstrar como foram ponderados todos os requisitos legais e demais elementos que justificassem a concessão ou a negativa da medida. Desse modo, o livre convencimento do juiz deve ser exercido respeitando-se as garantias adequadas e efetivas contra possíveis ilegalidades e arbitrariedades no procedimento em questão".
\end{abstract}

Acerca da duração das interceptações, a Corte Interamericana fixou que foi contrariada a parte final do art. 50, “o qual determina que a medida não poderá exceder ao prazo de 15 dias, podendo ser renovado por igual período de tempo, quando se comprove que a prova é indispensável”. 
Essas e outras decisões objetivam garantir o direito da pessoa humana, que é a finalidade maior do Direito. É certo que, quanto ao tema, o direito à intimidade é um dos fundamentos básicos do Estado Democrático de Direito, mas, todavia, esse foi entendido como relativo e não absoluto, tendo em vista a diversidade de direitos com seus respectivos valores igualmente consagrados.

Assim, em observância ao princípio da proporcionalidade, é que se aceita a violação ao direito à intimidade, mas, para que esse princípio possa ser adotado, é necessário que a medida tomada seja adequada, imprescindível e justa para a resolução do conflito com a plena realização da Justiça.

O que é inadmissível é que sejam editadas leis estabelecendo a excepcionalidade da medida e, depois, essas leis sejam descumpridas, expondo o indivíduo a situações atentatórias aos direitos humanos. 


\section{VII - CONCLUSÃO}

Pelo exame efetuado constata-se que as nações democráticas, como regra, procuram garantir a privacidade de seus cidadãos, coibindo, através de normas constitucionais, quebras de sigilo, sem que as mesmas se mostrem imprescindíveis para a colheita de prova em matéria criminal.

Há de se reconhecer que a sofisticação de que se valem certos grupos criminosos fez com que exceções fossem instituídas, de modo a que os integrantes de tais grupos possam sofrer resposta penal que esteja demonstrada mediante prova que ofereça certeza quanto à procedência da pretensão punitiva estatal.

O que não deve ser admitido é que a comprovação de condutas delituosas fique restritiva à interceptação das comunicações telefônicas, ou seja, restrinjam-se as autoridades a requerer a quebra do sigilo, e, posteriormente, o Ministério Público, com lastro, única e exclusivamente nas mesmas, venha a deflagrar a ação penal.

Ao nosso ver, desde que constatada a prática de conduta ilícita, deve ser instaurado o procedimento investigatório, de sorte a que sejam apurados indícios razoáveis de autoria ou participação. Caso fique constatado que a prova não possa ser produzida por outros meios, o que deve ser devidamente demonstrado, aí sim, justifica-se o requerimento da medida excepcional.

Entretanto, o que tem sido visto em muitos casos é que, sem início de qualquer forma apuratória, as autoridades partam para a lei do menor esforço, qual seja, pleiteiem a quebra do sigilo das interceptações 
telefônicas e, posteriormente, limitem-se à transcrição daquelas que possam interessar para incriminar o investigado.

A intenção do legislador, diga-se mais uma vez, não foi abolir as investigações, pois, se assim fosse, a policia judiciária seria de todo desnecessária e, ao invés de ser medida de exceção, constituir-se-ia em regra.

Não são raros os casos em que o Ministério Público contenta-se com as degravações que recebe, louvando-se nelas oferece denúncia, na qual não se propõe a produzir qualquer prova e, depois, pleiteia a procedência dos termos acusatórios e vem a ter acolhido o seu pedido.

Ao nosso ver, as conversações colhidas por meio de interceptações, quando isoladas e sem amparo em qualquer outro meio probatório, não deveriam servir de prova para fundamentar decisão condenatória, uma vez que não passa pelo crivo do contraditório.

Se é certo que a confissão colhida na fase inquisitória, por si, não se presta para a condenação, se não estiver corroborada por outros elementos, o que dizer-se então de conversações obtidas em momento em que o agente não sabe que está tendo os seus diálogos gravados ? Na confissão, em que o agente, por imposição constitucional, deve ser alertado que não está obrigado a prestar declarações e que o seu silêncio não será levado em consideração para fins condenatórios, a mesma, isoladamente, não é prova bastante para que ele receba resposta penal.

Neste trabalho procuramos, fundamentalmente, apresentar o posicionamento jurisprudencial de nossos tribunais, eis que estes tratam de casos concretos que revelam o cometimento de abusos, que acabam por ocasionar a nulidade de processos, muitos dos quais que apuram infrações penais da maior gravidade. 
Mas, essas decisões só podem ser motivo de aplauso e do engrandecimento do Judiciário, pois, dizendo respeito a lei que trata de medida excepcional, as suas disposições teem que ser rigorosamente observadas, sob pena de alcançarem excessos e abusos que acabarão por atingir pessoas de bem.

E, o que é pior, é que essas pessoas de bem, pela inobservância dos ditames da lei, acabam por ser expostas à execração pública, por terem seus diálogos divulgados através da mídia, em evidente quebra do segredo de justiça, o que constitui conduta delituosa prevista no art. 10, sujeitando os seus infratores ao recebimento de pena de reclusão.

Além do mais, segundo se nos afigura, melhor seria que a lei seguisse a sistemática da legislação de outros países, pois, ao invés de estabelecer quais as hipóteses impeditivas da utilização da medida, deveria prever os casos em que ela poderia ser admitida.

Ao prever que a interceptação não pode ser decretada quando o fato investigado constituir delito punido com a pena de detenção, passou a permitir a sua imposição em todos os delitos que impõem pena de reclusão. Ora, atualmente, várias são as figuras penais que, embora estabeleçam pena de reclusão, são consideradas infrações penais de menor potencialidade ofensiva, sendo que alguns delas, podem ter suspenso o processo, nos termos do art. 89, da Lei $n^{0}$ 9.099/95.

Dentre os excessos praticados, a mídia tem noticiado que advogados, juízes e até mesmo desembargadores, tiveram a sua privacidade violada, mediante invasão clandestina em seus escritórios e gabinetes de trabalho. 
No que se refere aos advogados, recentes notícias dos jornais divulgaram a quebra do sigilo quando os mesmos, em entrevistas com seus clientes em parlatórios de presídios, tiveram gravadas as suas conversações.

Tal prática, como não poderia deixar de ser, mereceu severa crítica do mundo jurídico e da Ordem dos Advogados do Brasil, pois, tal procedimento atenta contra expressa disposição do art. $7^{\circ}$, inciso II, da Lei no 8.906/94, e, sobretudo, do art. 133, da Constituição Federal.

Como destacado em título próprio deste trabalho, raros não teem sido os casos em que, em razão de denúncias anônimas, as autoridades começam as investigações mediante representação apresentada ao Judiciário, o qual, infelizmente, tem deferido as interceptações, o que tem motivado que as Instâncias Superiores tenham determinado o desentranhamento das degravações produzidas e, por derivação, considerado provas delas advindas como ilícitas.

Mas, certamente, as maiores discussões que teem chegado ao Judiciário dizem respeito à falta de fundamentação das decisões que autorizam as interceptações.

A Lei $n^{\circ} 9.296 / 96$, por excesso, em seu art. $5^{\circ}$, exige que as decisões sejam devidamente fundamentadas, o que, inclusive, seria desnecessário, na medida em que o art. 93, inciso IX, da Carta Magna, impõe tal obrigatoriedade para toda e qualquer decisão judicial.

Todavia, na pesquisa jurisprudencial realizada, encontramos algumas decisões que decretaram essa excepcional medida, utilizando-se o seu prolator de meia dúzia de linhas, nas quais, evidentemente, não consegue demonstrar a necessidade da mesma. 
Então, nas criticáveis prorrogações sucessivas, os magistrados teem sido ainda mais omissos, uma vez que, na grande maioria das vezes, limitam-se a reproduzir decisões anteriores e até mesmo manifestação do Ministério Público, quando a parte final do art. 5º impõe a demonstração da sua indispensabilidade.

Aliás, as sucessivas prorrogações que teem sido deferidas, muito embora tenham sido prestigiadas pelos Tribunais, hoje já são objeto de críticas, pois, tantos foram os abusos cometidos, que ultrapassaram as raias da razoabilidade e, por isso, algumas Cortes, teem revisto suas decisões, para coibir a infinidade com que estão sendo utilizadas.

Não parece crível e nem essa foi a intenção do legislador, que as interceptações possam perdurar por anos a fio, em evidente violação da privacidade do cidadão, de sua família e de seus amigos, numa cadeia infindável de ilegalidades.

Em casos que tais, cria-se uma verdadeira teia de aranha, em que alguém fala com outrem e, se este usa qualquer frase que seja interpretada como duvidosa, ele também acaba por ser atingido pela interceptação e assim vai sucessivamente.

Um outro ponto que nos chamou a atenção é a utilização das interceptações para outros fins probatórios que não sejam a investigação criminal ou instrução penal.

Inobstante se reconheça que o Excelso Pretório tenha admitido que as interceptações possam ser utilizadas, como prova emprestada, em outros procedimentos, cremos que essa interpretação não condiz com os termos da lei, que são taxativos e, na condição de medida excepcional, devem ser interpretados de forma restritiva. 
Enfim, este era o trabalho de monografia que nos propusemos a apresentar. Esperamos que a compreensão da banca se mostre benevolente na aceitação das considerações que apresentamos, uma vez que se trata de tema que sofre questionamentos doutrinários e jurisprudenciais que só o tempo ou a mudança da lei irá consolidá-los.

De qualquer maneira e modo, a pesquisa feita foi altamente recompensadora, pois, como cidadã, acompanhei algumas projeções da mídia que, num primeiro momento, impressionaram-se e que, agora, estou constando que a sua divulgação constitui violação a garantia constitucional que o operador do Direito não pode admitir.

Tenho consciência que não esgotei a matéria, mas, como mera bacharelanda, acredito que fiz o melhor, notadamente, porque procurei examinar de forma concreta o tema, tratando-o da forma que os tribunais o veem interpretando.

Para concluir, não posso deixar de agradecer a atenção que a banca venha dispensar a este trabalho, esperando que ele seja aceito, de modo a possibilitar-me a alcançar a condição de advogada e credenciada para atingir outras condições que me habilitem a ingressar no mundo jurídico. 


\section{REFERÊNCIAS BIBLIOGRÁFICAS}

BASTOS, Celso Ribeiro. Comentários à Constituição do Brasil, vol. II

Boletins do IBCCrim de ${ }^{0}$ s. 38, 40, 44, 45, 47, 51, 54, 55, 56, 65, 70 e 213.

GOMES, Luiz Flávio. Interceptação Telefônica, ed. Revista dos Tribunais.

GOMES, Luiz Flávio. A CPI e a Quebra do Sigilo Telefônico, Cadernos

“Direito e Justiça”, Correio Braziliense de 28.04.1997.

GRECO FILHO, Vicente. Interceptação Telefônica, ed. Saraiva.

GRINOVER, Ada . Novas Tendências do Direito Processual, ed. Forense Universitária, 1990.

GRINOVER, Ada Pellegrini e Outros. As Nulidades no Processo Penal, 10a . ed. rev., atual. e ampl., São Paulo, Rev. dos Tribunais, 2007.

JESUS, Damásio. Interceptação de Comunicações Telefônicas, ed. Revista dos Tribunais.

MENDES, Carlos Alberto Pires e TEIXEIRA, Fernanda Velloso - Boletim IBCCrim $n^{0} 41$;

PRADO, Geraldo. Limite às Interpretações Telefônicas e Jurisprudência do Superior Tribunal de Justiça, Lúmen Júris Editora. 
RANGEL, Paulo. Interceptação Telefônica, Revista Forense nº 344.

Revista Brasileira de Ciências Criminais, vol. 7, ed. Revista dos Tribunais.

SILVA, José Afonso da. Curso de Direito Constitucional, 11ª. ed., São Paulo, Malheiros, 1996.

TOURINHO FILHO, Fernando da Costa. Processo Penal, 16a . ed., vol. III, São Paulo, Saraiva, 1994. 